Article

\title{
Analyzing the Online Reputation and Positioning of Airlines
}

\author{
Ayat Zaki Ahmed $\mathbb{D}$ and Manuel Rodríguez-Díaz * \\ Department of Economics and Business, University of Las Palmas de Gran Canaria, 35001 LasPalmas, Spain; \\ ayatzaki@hotmail.com \\ * Correspondence: manuel.rodriguezdiaz@ulpgc.es; Tel.: +34-928-452-805
}

Received: 18 December 2019; Accepted: 1 February 2020; Published: 6 February 2020

\begin{abstract}
The aim of this study is to propose a methodology to define the positioning of airlines in terms of their online reputation measured with quantitative variables and applied in the airline industry. Reviews shared on the Internet give key information about service quality and value as perceived by customers. To carry out the empirical study, we obtained the information available on TripAdvisor about airlines in Europe, the USA, Canada, and other countries in America, differentiating also between airlines that follow a low-cost strategy and those that do not apply it. The results show that there is a significant difference in key service quality variables between airlines in the different geographical areas studied on the one hand, and the low-cost strategy applied on the other. The variables to be used to conduct the positioning analysis in the airlines are determined. They also show that the methodology has relevant practical implications and provides tools to further develop research related to the online reputation and strategic positioning of airlines.
\end{abstract}

Keywords: online reputation; airlines; market positioning; customer value; service quality; online customer review

\section{Introduction}

Customers' ratings of a product, service, or brand through different social media on the Internet constitute its online reputation [1-4]. Currently, the image transmitted through the Internet is a key factor in the ability to compete. To some extent, it is beyond the control of companies because customers or users can freely share their opinions. Moreover, unreal or biased opinions aimed at conditioning the reputation of brands or companies may be expressed [5,6]. All customer messages and evaluations over the Internet make up the current word-of-mouth or E-WOM communication [7-12]. However, although some of this information is generated outside companies, they can develop strategies to make this feedback fit reality. In this context, the analysis of the credibility of sources of online reputation and E-WOM is essential to define the most reliable communication channels over the Internet $[13,14]$. Likewise, companies can take advantage of the synergies produced by shared opinions, obtaining high visibility and impact in different social media $[15,16]$. The online reputation gap analysis proposed by Rodriguez-Díaz et al. [17] suggests tools or methods designed to ensure that the online reputation coincides as closely as possible with the perceptions customers have when they receive a service or buy a product.

Kotler and Armstrong [18] consider that positioning is based on designing the company's marketing strategy in such a way that it holds a clear and valued place in the minds of consumers. Thus, the positioning of a brand, product, or service is the place it holds in the minds of consumers in relation to its competitors. Adequate positioning is essential for the company's brand image or goods and services, and it is a fundamental tool to differentiate it from competitors. From a practical perspective, positioning consists of an association or relationship between a brand or product and a 
series of attributes that customers have the ability to identify and evaluate in relation to competitors. Based on this approach, the online reputation provides customer assessments of key attributes of brands, products, or services that compete with each other in the same market [19]. Therefore, it is a new way to easily obtain information about the position of different competing products or services in the minds of customers.

Ratings of online reputation can be quantitative and qualitative, and they are currently a powerful tool for attracting demand, increasing revenue, and achieving a position ahead of competitors [20-22]. The opinions shared through quantitative variables are usually structured on measurement scales of attitudes and perceptions. Therefore, customer ratings can be evaluated using conventional statistical techniques that determine the degree of reliability and validity of the scales [23,24]. Likewise, these types of variables allow competitive positioning studies to be carried out using a relatively simple procedure [25]. In this context, positioning is determined through customer ratings of certain variables that measure key attributes of products, services, or brands that compete directly in the market [19,26-29].

Quantitative evaluations on the Internet often measure a small number of variables in order to encourage clients to fill out surveys $[5,15,16,25,30,31]$. Generally, scales of less than eight variables are used to measure the perceived service quality and, in many cases, the perceived value construct [32-34]. By contrast, qualitative assessments are obtained from the opinions written by users. Through content analysis, firms can measure customer satisfaction, which is more related to experiences, emotions, and feelings that generate a positive or negative affective state in the customers of the service or product consumed $[15,35,36]$. Online reputation has been widely studied in the tourism sector, with a great impact on capturing the demand for hotels [37]. From the perspective of quantitative research, online customer ratings have been used preferentially on the specialized websites of TripAdvisor, Booking, and HolidayCheck [25,38-41]. However, in the airline sector, research has been limited, especially in the statistical analysis of the scales and competitive positioning studies [42-44].

The objectives of this study are twofold: (1) to propose a methodology for positioning analysis based on online reputation measured with quantitative variables and (2) to apply this methodology to the airline sector in order to demonstrate that, as in the hotel sector, competitive positioning studies can be carried out based on the online opinions of customers with quantitative variables. TripAdvisor uses a scale where most of the variables measure the perceived quality of service, using a single variable to determine the value perceived by users [45]. The value construct is usually measured in different ways using the variable "value for money" or " price-quality relationship". It is quite interesting to analyze the relationship between the service quality and the perceived value in the online reputation because as they are related constructs and usually used to establish the predictive validity of service quality scales. Because value is a concept that involves price, it is very useful in determining the competitive positioning of brands or companies in the market [19]. Today, positioning is an essential factor in gaining a competitive advantage through differentiation or cost leadership, by offering relevant Internet information to determine how an airline is rated by its customers in relation to its competitors.

The article begins with a review of the literature on online reputation and the importance it has in different service companies such as airlines. Next, the methodology applied in the empirical study is explained. Subsequently, the results obtained in the statistical analyses and in the positioning of the airlines based on the constructs of perceived value and perceived service quality are presented. Finally, the main conclusions drawn and the most relevant practical and research implications are described.

\section{Literature Review}

The reviews clients share on the Internet have been used in various research studies in the services sector [19,25-29]. Mudambi and Schuff [4] consider online customer opinions to be quantitative or qualitative evaluations of brands, products, or services that are transmitted to other users and companies through social media available on a website. From this perspective, online opinions are becoming a new source of information to measure the quality of the service and the perceived value of 
the products or services consumed $[23,24,33]$. In this context, online reputation is a simple and useful way to measure customer perceptions [20,46-48] and establish the level of satisfaction obtained [49-53].

Online reputation is generated through an open and dynamic process based on the ratings of a product, service, brand, or company that customers share on the Internet [2,54], creating an image that conditions the buying attitude of other potential customers $[1,17]$. To the extent that the online reputation is generated through the assessment of scales of variables and opinions, it can be measured with three essential concepts: perceived service quality, perceived value, and satisfaction. In this context, Torres [34] points out that service quality is normally measured with specific quantitative variables, whereas satisfaction is a general appraisal related to experience and emotions. In this regard, Rust and Oliver [55] establish the differences between service quality and satisfaction by stating that, whereas the former is usually measured with quantitative variables, satisfaction is usually established with more generic qualitative evaluations that may also include attributes of service quality.

Service quality is measured through customers' perceptions every time they receive a service [32,56-60]. By contrast, satisfaction is the consequence of diverse experiences, where a client determines what he feels and values about the product or service received [49-51]. Based on these considerations, the scales of variables used by the specialized TripAdvisor, Booking, and HolidayCheck websites normally measure service quality attributes or perceived value [23,24]. In addition, the written comments left by users on these websites gather essential information about the satisfaction obtained. This study analyzes the online reputation of airlines based on TripAdvisor's scale of variables. Therefore, these dimensions quantitatively measure perceived service quality, using a single variable to measure perceived value [25].

The quality of service has been studied with various scales of variables [61-65], especially the SERVQUAL formulated by Parasuraman et al. [56], which is composed of five dimensions or underlying factors (tangibility, reliability, responsiveness, security, and empathy). However, specialized web pages tend to use scales with a lower number of variables in order to encourage users to share their evaluations on the Internet. In this regard, Rodríguez-Díaz and Espino-Rodríguez [23] statistically analyze the quantitative variable scales of TripAdvisor, Booking, and HolidayCheck, demonstrating their reliability and validity for measuring perceived service quality. Therefore, reducing the number of variables to assess service quality requires a careful selection of variables to measure basic attributes $[15,16]$.

Research carried out by Ye et al. [25] and Rodríguez-Díaz et al. [19] demonstrates that the TripAdvisor and Booking scales for assessing online reputation actually measure two concepts: perceived service quality and perceived value. Service quality is determined by most of the scales' variables, whereas perceived value is measured by a single item. Value is a subjective concept related to what a customer receives from a product or service in relation to the cost of acquiring it $[48,54,65]$. Perceived value is usually measured with multiple-item scales [30,66-68]. Nevertheless, according to Prebensen et al. [45], on certain occasions it is measured with only one item. This is the case of online reputation, where TripAdvisor, Booking, and HolidayCheck evaluate the perceived value in the tourism sector with a single variable. For the airlines, TripAdvisor has developed a scale of eight specific variables to measure online reputation, using a single item (value for money) to measure perceived value.

There is a strong relationship between airline image and reputation which influences the processes of the positioning of airlines. Reputation theory was originally developed in the 1950s when the concept of corporate image emerged [69,70]; it was also defined as the customer's accumulated impression of a company resulting from their interactions with the company [71]. Airline image is built on communication programs like advertising mechanisms [72] and social media [73]. The airline image is defined as the immediate mental picture that passengers have of an organization [74]. A favorable reputation has a positive influence on the company's success [75] and good airline image may enhance its reputation. Chen [76] demonstrated that the customer's general attitudes towards an airline have a positive effect to their loyalty. In the air travel industry, companies make a lot of efforts to build powerful brand images aiming to increase passenger trust [77]. Service is one of the important factors 
for determining the airline image, whereas other attributes like schedules and fare offers have little influence on corporate image [78]. Airlines can use market brand positioning to identify major strengths and weaknesses within their services such as comfort of seats, cleanliness, check-in and boarding, airline image, and travel cost and time [79]. The study conducted by Lucini et al. [80], based on content analysis of online opinions of airline customers, determines the dimensions of customer satisfaction, making a prediction of the possibility of recommending the airline or not. It is a very interesting study because it is based on the qualitative opinions that customers share on the Internet. However, the analysis of quantitative variables is also of great interest, insofar as it provides generalizable information that can be a powerful business management tool.

Kotler and Armstrong [18] state that positioning must be defined on the basis of customers' assessments of a brand or product in relation to its competitors. Implementing a positioning strategy requires taking into account that differentiation is a decisive factor in companies' competitiveness. Furthermore, the product must be difficult to imitate in the short term, it must bring benefits that the customer values, and it must be profitable for companies. Therefore, positioning is an essential tool in marketing in general and, nowadays, in digital marketing, because users increasingly become informed on the Internet before making their purchase decisions [81]. From this perspective, the competitiveness that companies obtain through adequate positioning is a means to achieve an economic result that is sustainable over time in an increasingly dynamic market [82].

Positioning is a basic tool for defining a company's competitive strategy. Hooley et al. [26] consider that the position a company decides to occupy in the market is a combination of the target market it wants to reach and the differential advantage it wants to develop to guarantee that target market. This means that competitive positioning must be based on detecting the needs of consumers, in order to satisfy them under better conditions than competitors. Therefore, the market is what determines the positioning of companies, and the clients rate them according to a set of variables [27]. In relation to online reputation, it is evident that it provides key variables to measure the service quality and value perceived by customers. From this perspective, the online reputation gives market information, not only about a particular company, but also about its competitors [81]. This information facilitates the development of companies' competitive positioning in highly relevant service sectors, such as hotels or airlines.

Obviously, Internet positioning studies can be carried out by analyzing different types of variables from different viewpoints $[81,83,84]$, but in this case it is analyzed from the perspective of competitive marketing positioning. The online reputation produces information that is immediately transmitted to any potential client, communicating a mental image of a brand or product in relation to its competitors [19]. Ratings shared through social media influence customers' purchasing behavior and, therefore, their income and competitiveness $[85,86]$.

This study carries out an analysis of the online reputation of airlines, based on the scale of quantitative variables used by TripAdvisor. This scale basically measures the perceived service quality with seven variables, using a question to measure the value perceived by customers $[19,25]$. With these data, a study of competitive positioning is undertaken, where perceived value plays an essential role because it intrinsically incorporates the price of the goods in the rating $[67,81]$.

\section{Research Methodology}

The methodology proposed to carry out a positioning analysis based on online reputation measured with quantitative variables is shown in Figure 1. We propose eight stages that begin by determining the web or social media from which the information will be extracted to make the positioning analysis. From this perspective it can be seen that each website has a different scale of variables with different response alternatives [23]. The second step is to obtain information from a relevant number of companies competing in the same sector that will guarantee a representation of the market under study. It is essential to obtain a minimum amount of data that guarantees the reliability of the statistical analyses that are carried out. The sample must include data from the company or 
brand carrying out the study as well as from the most direct competitors. The next step is to identify the scale of variables that the web uses to measure online reputation. Each of the variables must be analyzed in order to determine if it really affects specific attributes that depend exclusively on the management of the companies. For example, Wi-Fi is an essential aspect for the competitiveness of hotels but, in many cases, having good connectivity also depends on external agents that provide the connections. In step four we proceed to analyze the content of the scale of variables in terms of the constructs being measured. A characteristic of scales to assess online reputation is that they have a very limited number of quantitative variables that normally measure perceived service quality, and sometimes only one variable is included to measure perceived value [45].

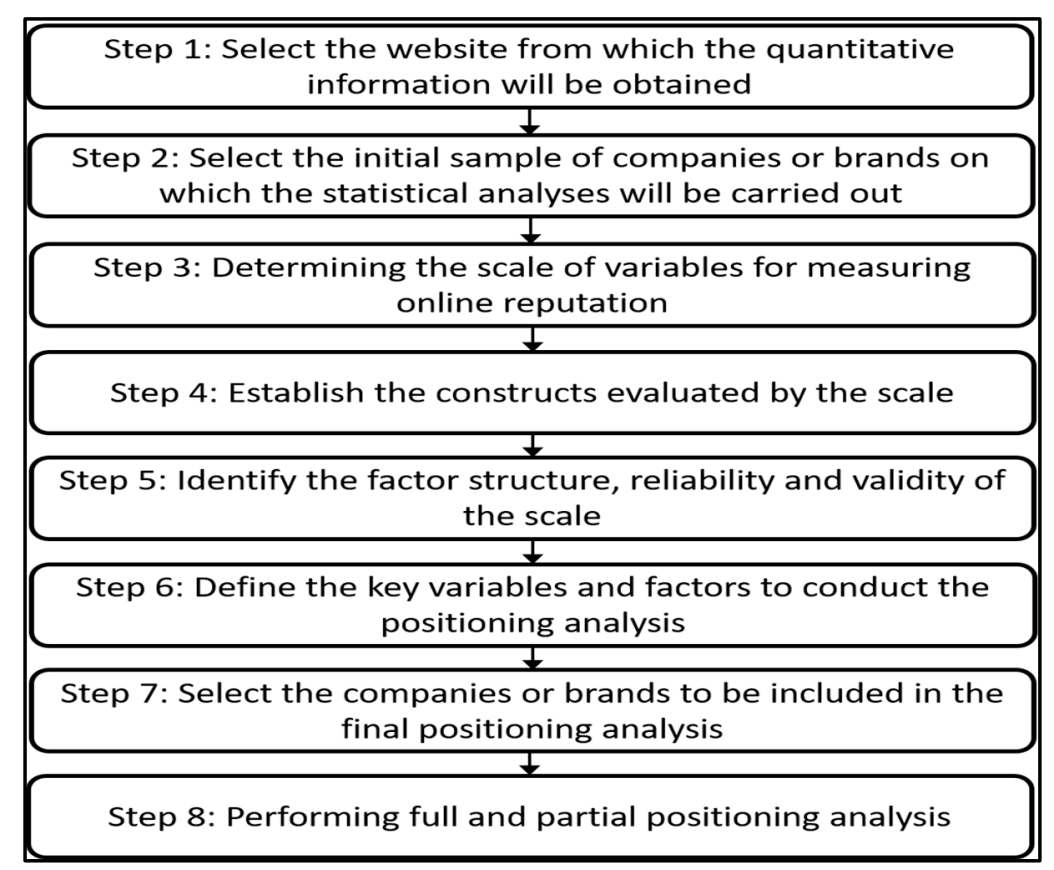

Figure 1. Methodology for positioning analysis based on online reputation measured with quantitative variables.

The fifth step focuses on analyzing the reliability and validity of the scale of quantitative variables. This is an essential aspect to demonstrate that the online reputation information collected on the web can be used to perform competitive positioning analysis. The sixth step identifies the variables and factors that are significant to use in positioning analysis. To do this, it is necessary to determine the dimensions to be used in the positioning analysis. In this study the variables of perceived service quality and perceived value are used. Therefore, it must be shown that there is a significant relationship between both constructs, either at the level of service quality variables or as a joint factor.

Once the information has been tested to be reliable and valid and the key variables and factors to perform the positioning analysis have been identified, a new, more specific selection of more direct competitors can be made in step seven. In this study, the study was carried out both globally and by groups of companies. Given that each company must set the selection criteria for the sample in which it is most interested, in this study we have proceeded to apply the positioning methodology by categorizing the airlines according to two criteria. On the one hand, they have been classified according to the market in which they operate, differentiating between Europe, the USA, and Canada. and the rest of the countries in America. A second classification has been made according to if their strategy is low-cost or not. The purpose is to monitor more specifically those competitors that can have a greater influence on the market segments a company or brand is targeting. Finally, positioning analyses are carried out either at a global level or with more specific competitors depending on the variables and key factors identified. 
The empirical study was carried out taking into account the TripAdvisor ratings of 134 airlines. The total number of comments used to obtain online reputation scores was 641,448 . Fifty-one airlines are from Europe, 21 from the United States, 15 from Canada, and 47 from other American countries. The study can be carried out by grouping the airlines according to different rules. In this case, the geographical area where the companies are most active is the criterion used. The purpose is to detect whether there are significant differences between customers depending on where they reside. The aim of this study is to demonstrate that the methodology proposed to conduct competitive positioning based on online reputation is feasible and useful for airlines.

In order to apply the statistic methodology through the factor analyses, regressions, and positioning, groups of companies were formed according to two criteria: (1) the geographical area where they fly and (2) the low-cost or non-low-cost strategy followed by the airlines. In relation to the geographical areas, one cluster was formed with the European airlines (352,277 reviews); one cluster contained the rest of the American countries (87,268 reviews); and, finally, the airlines from the United States and Canada were combined in the same cluster containing a total of 36 companies and 202,405 customer online evaluations (see Table 1). The TripAdvisor scale has five alternatives for rating airlines, where 1 is "terrible", 2 "poor", 3 "average", 4 "good", and 5 "excellent". This scale of variables has been statistically validated in different studies, such as those conducted by Ye et al. [25] and Rodríguez-Díaz and Espino-Rodríguez [23]. With regard to the strategy implemented, in Table 1 the airlines that follow a low-cost strategy are marked with an asterisk.

Table 1. Airlines studied.

\begin{tabular}{|c|c|c|}
\hline EUROPE & USA and CANADA & OTHER COUNTRIES IN AMERICA \\
\hline Aegean Airlines & Mokulele Airlines & * Andes Lineas Aereas \\
\hline Canaryfly & * Southern Airways Express & Avianca \\
\hline Air Europa & * Tradewind Aviation & Aerolineas Argentinas \\
\hline Air France & * Avior Airlines & Austral Lineas Aereas \\
\hline Alitalia & * Laser Airlines & * Flybondi \\
\hline American Airlines & Alaska Airlines & LATAM Airlines \\
\hline Binter Canarias & * Allegiant Air & * Aruba Airlines \\
\hline British Airways & American Airlines & * Bahamasair \\
\hline Caribbean Airlines & Delta Air Lines & Maya Island Air \\
\hline Cathay Pacific & * Frontier Airlines & Tropic Air Belize \\
\hline${ }^{*}$ Condor & Hawaiian Airlines & Azul \\
\hline Ethiopian Airlines & * JetBlue & * GOL Airlines \\
\hline Etihad Airways & * Southwest Airlines & Passaredo Linhas Aereas \\
\hline * Eurowings & * Spirit Airlines & Cayman Airways \\
\hline * Evelop & * Sun Country Airlines & * JetSmart \\
\hline * Germania Airlines & United Airlines & *Sky Airline \\
\hline Iberia & Cape Air & * EasyFly \\
\hline * Iberia Express & Elite Airways & * SATENA Colombia \\
\hline * Japan Airlines (JAL) & * Silver Airways & * VivaColombia \\
\hline * Jet2.com & * Via Air & * Wingo \\
\hline KLM Royal Dutch Airlines & * Air Choice One & * Nature Air \\
\hline * LOT Polish Airlines & Air Canada & * SANSA \\
\hline
\end{tabular}


Table 1. Cont.

\begin{tabular}{|c|c|c|}
\hline EUROPE & USA and CANADA & OTHER COUNTRIES IN AMERICA \\
\hline Lufthansa & * Air Canada Rouge & Aerogaviota \\
\hline Malaysia Airlines & Air North & * Cubana de Aviacion \\
\hline * Norwegian & * Air Transat & * PAWA Dominicana \\
\hline Olympic Air & Bearskin Airlines & * TAME \\
\hline *Qantas & Canadian North & Air Greenland \\
\hline Saudia Airlines & * Central Mountain Air & ${ }^{*}$ Air Antilles \\
\hline Brussels Airlines & First Air & Air Caraibes \\
\hline China Airlines & * Flair Airlines & * Aerolineas Sosa \\
\hline * EasyJet & Pacific Coastal Airlines & CM Airlines \\
\hline * Finnair & Pascan & Aeromar \\
\hline * Aer Lingus & Porter Airlines & ${ }^{*}$ Aeromexico \\
\hline${ }^{*}$ Aeroflot & PAL Airlines & * Calafia Airlines \\
\hline * SriLankan Airlines & * Sunwing Airlines & * Interjet \\
\hline Swiss International Air Lines & * WestJet & * Magnicharters \\
\hline TAP Portugal & & * TAR Aerolineas \\
\hline * TAROM & & * Volaris \\
\hline Thai Airways & & Air Panama \\
\hline * Thomas Cook Airlines (UK) & & * Copa Airlines \\
\hline * Thomas Cook Airlines Scandinavia & & * Peruvian Airlines \\
\hline * Transavia & & * Star Peru \\
\hline * TUI Airlines Netherlands & & * Air Flamenco \\
\hline * TUI Airways (United Kingdom) & & * Seaborne Airlines \\
\hline * TUI fly Belgium (formerly Jetairfly) & & *Vieques Air Link \\
\hline * TUIfly (Germany) & & *Winair \\
\hline * Tunisair & & * Surinam Airways \\
\hline \multicolumn{3}{|l|}{ Turkish Airlines } \\
\hline \multicolumn{3}{|l|}{ Ukraine International Airlines } \\
\hline \multicolumn{3}{|l|}{ * Vueling Airlines } \\
\hline * Wizz Air & & \\
\hline
\end{tabular}

Table 2 displays the description of the eight variables on the scale to determine the online reputation of airlines in TripAdvisor. The variables used to measure the perceived service quality are: comfort of seats (Cs), check-in and boarding $(\mathrm{Cb})$, food and drink (F), space for legs (Sl), service (Sv), cleanliness $(\mathrm{CL})$, and entertainment $(\mathrm{E})$. To establish the value perceived by customers, TripAdvisor uses the variable "value for money" (V). From these evaluations, TripAdvisor calculates the "airline's average score" (AAS), which is the mean obtained with this formula:

$$
A A S=\frac{(C s+C b+F+S l+S v+C l+E+V)}{8}
$$


Table 2. Description of variables.

\begin{tabular}{|c|c|}
\hline Variables & Description \\
\hline Airline's average score (AAS) & Reviewer's overall evaluation of the airplane and airline \\
\hline Comfort of seats (Cs) & The overall reviewer rating of the comfort of seats of the airplane \\
\hline Check-in and boarding $(\mathrm{Cb})$ & $\begin{array}{c}\text { The overall reviewer rating of the processes of check-in and boarding } \\
\text { the airplane }\end{array}$ \\
\hline Food and drink $(\mathrm{F})$ & The overall reviewer rating of the food and drink served during the flight \\
\hline Space for legs (Sl) & The overall reviewer rating of the space for legs in the airplane \\
\hline Service (Sv) & $\begin{array}{c}\text { The overall reviewer rating of the service received during the flight and by } \\
\text { the airline }\end{array}$ \\
\hline Cleanliness $(\mathrm{Cl})$ & The overall reviewer rating of the cleanliness of the airplane \\
\hline Entertainment $(\mathrm{E})$ & The overall reviewer rating of the entertainment during the flight \\
\hline Value for money $(\mathrm{V})$ & The overall reviewer rating of the perceived value of the airplane and airline \\
\hline
\end{tabular}

Ye et al. [25] differentiate between the variables to measure the perceived service quality and the variable used by TripAdvisor to determine the perceived value. Along the same lines, Rodríguez-Díaz et al. [19] establish the variable $Q$, calculated with the average of the service quality dimensions in the hotel reputation online scales. Adapting the variable $Q$ to the airplane sector, its value is determined with the following formula:

$$
Q=\frac{(C s+C b+F+S l+S v+C l+E)}{7}
$$

The main differences between this research and that carried out by Rodríguez-Díaz et al. should be highlighted at this point [19]. Firstly, while the research cited focuses on the tourism sector, this one focuses on airlines. Secondly, the methodology followed for positioning based on online reputation with quantitative variables is not specified with the same precision and breadth as in the study by Rodríguez-Díaz et al. Thirdly, tourist accommodations are evaluated on the basis of information available in Booking, while this is done in TripAdvisor. Fourthly, the scale of variables used by Booking measures the perceived quality of service of hotels using the variables of location, staff, comfort, cleanliness, facilities and service, and Wi-Fi, while the scale of variables used by TripAdvisor to measure the quality of service of airlines is shown in Table 2. Fifthly, among the possible future investigations raised in the above-mentioned research is that of carrying out positioning studies in other service sectors, in order to verify whether online reputation is valid for carrying out positioning studies. Finally, this research, due to its approach, the sector under study, the website used, the scale of variables used, and the methodology to be followed in depth, represents a novel and significant advance in this interesting line of research.

\section{Analysis of Results}

The analysis of the results consists of three parts. In the first, a factorial analysis is carried out to determine the dimensions of the scale of variables used by TripAdvisor to measure the online reputation of airlines. A reliability analysis is also performed using Cronbach's Alpha. In the second part, multiple regression analysis is conducted, where the variable to be explained is the perceived value and the independent variable is the perceived service quality scale. The aim is to determine which of the seven variables on the service quality scale is most related to the perceived value. This is a method for determining the predictive validity of the scale, given that perceived service quality and perceived value are interrelated constructs [23,24]. Finally, the positioning analysis is undertaken, always using the perceived value as a reference variable because it includes the price paid by customers. Positioning analysis is carried out in two ways, by variable and by regression. The former is performed with the variables that are related to the perceived value, whereas the latter is carried out by means of 
a bivariate regression between the perceived value and the perceived service quality factor. All the statistical analyses were carried out for all the airlines together and for each of the groups individually.

\subsection{Factor Analysis}

In order to verify the one-dimensionality and reliability of the TripAdvisor service quality scale, Ye et al. [25] carried out a factorial analysis with the following equation:

$$
\text { Qf }=\alpha 0+\alpha 1 \mathrm{Cs}+\alpha 2 \mathrm{Cb}+\alpha 3 \mathrm{~F}+\alpha 4 \mathrm{Sl}+\alpha 5 \mathrm{~Sv}+\alpha 6 \mathrm{Cl}+\alpha 7 \mathrm{E}+\varepsilon
$$

The factorial analysis was carried out for all the airlines together and for each of the three defined airline groups (Europe, United States-Canada, and other countries in the Americas) (see Table 3). The Kaiser-Meyer-Olkin (KMO) test yielded results above 0.8 , and all Bartlett's tests were significant, whereas the variance explained in all the analyses exceeded 70\%. The variance explained for the other countries in America was $76.53 \%$, whereas all the companies as a whole reached $73.31 \%$. Moreover, Cronbach's alpha scores were above 0.9 in all the analyses, confirming the reliability of TripAdvisor's perceived service quality scale. Table 3 also shows the results of the factor analysis where the airlines are differentiated according to their strategy. It can be seen that the low-cost airlines only identify one factor, which explains $79.21 \%$ of the variance with a Cronbach's Alpha of 0.786 . On the contrary, in the rest of the airlines, two factors are obtained that explain $78.14 \%$ of the total variance. In the first one, the variables of comfort of seats, food and drink, space for legs, and entertainment are assigned, obtaining a 0.786 of reliability. For its part, the second factor integrates the key variables of check-in and boarding, service, and cleanliness obtaining a Cronbach Alpha of 0.933.

The results show that the scale of variables used by TripAdvisor to measure the online reputation of airlines is one-dimensional and reliable in the geographical area classification and in the low-cost strategy. By contrast, airlines that do not follow a low-cost strategy obtain two factors whose variables reach a high reliability indicator. This is an analysis that has to be carried out before the positioning definition, in order to demonstrate that the data and variables to be used are reliable as well as to determine the factorial structure of the scale of variables.

Table 3. Factor analysis.

\begin{tabular}{ccccc}
\hline & $\begin{array}{c}\text { All } \\
\text { Companies }\end{array}$ & Europe & $\begin{array}{c}\text { USA and } \\
\text { Canada }\end{array}$ & $\begin{array}{c}\text { Other Countries } \\
\text { of America }\end{array}$ \\
\hline Variables & $\mathbf{1}$ Factor & 1 Factor & 1 Factor & 1 Factor \\
\hline Comfort of seats & 0.913 & 0.901 & 0.927 & 0.929 \\
\hline Check-in and Boarding & 0.899 & 0.882 & 0.916 & 0.913 \\
\hline Food and drink & 0.890 & 0.875 & 0.903 & 0.906 \\
\hline Space for legs & 0.883 & 0.853 & 0.893 & 0.895 \\
\hline Service & 0.869 & 0.851 & 0.862 & 0.888 \\
\hline Cleanliness & 0.818 & 0.814 & 0.757 & 0.817 \\
\hline Entertainment & 0.703 & 0.668 & 0.620 & 0.763 \\
\hline Fariance explained & $73.31 \%$ & $70.23 \%$ & $71.59 \%$ & $76.53 \%$ \\
\hline Cronbach's Alpha & 0.938 & 0.928 & 0.931 & 0.948 \\
\hline Kaiser-Meyer-Olkin Measure of Sampling & 0.860 & 0.826 & 0.804 & 0.867 \\
\hline Adequacy. & 1021.364 & 291.524 & 286.018 & 357.473 \\
\hline Bartlett's Test of Sphericity Approx. Chi-Square & 21 & 21 & 21 & 21 \\
\hline dig. & 0.000 & 0.000 & 0.000 & 0.000 \\
\hline
\end{tabular}


Table 3. Cont.

\begin{tabular}{|c|c|c|c|}
\hline $\begin{array}{c}\text { All } \\
\text { Companies }\end{array}$ & Europe & $\begin{array}{l}\text { USA and } \\
\text { Canada }\end{array}$ & $\begin{array}{c}\text { Other Countries } \\
\text { of America }\end{array}$ \\
\hline & Low-cost & \multicolumn{2}{|c|}{ Non-low-cost } \\
\hline Variables & 1 Factor & 1 Factor & 2 Factor \\
\hline Comfort of seats & 0.929 & 0.843 & \\
\hline Check-in and boarding & 0.922 & & 0.933 \\
\hline Food and drink & 0.859 & 0.806 & \\
\hline Space for legs & 0.906 & 0.846 & \\
\hline Service & 0.939 & & 0.929 \\
\hline Cleanliness & 0.905 & & 0.879 \\
\hline Entertainment & 0.756 & 0.755 & \\
\hline \multicolumn{4}{|c|}{ Factor analysis and reliability indicators } \\
\hline Variance explained & $79.21 \%$ & \multicolumn{2}{|r|}{$78.14 \%$} \\
\hline Cronbach's Alpha & 0.948 & 0.786 & 0.920 \\
\hline Kaiser-Meyer-Olkin Measure of Sampling Adequacy. & 0.888 & \multicolumn{2}{|r|}{0.709} \\
\hline Bartlett's Test of Sphericity Approx. Chi-Square & 635.677 & \multicolumn{2}{|r|}{310.659} \\
\hline $\mathrm{df}$ & 21 & \multicolumn{2}{|r|}{21} \\
\hline Sig. & 0.000 & \multicolumn{2}{|r|}{0.000} \\
\hline
\end{tabular}

\subsection{Multiple Regression Analysis}

The results of the multiple regression analyses can be found in Table 4 . The table shows that the six regressions obtained very satisfactory results from a social science perspective because all the adjusted $\mathrm{R}$ squares are above 0.60 . This shows that there is a close relationship between the perceived service quality and perceived value constructs. These results also confirm the predictive validity of the quality of service scale used by TripAdvisor. However, the results show that a small number of variables are significantly related to value. Therefore, there is a close relationship between the perceived service quality and the perceived value, due to obtaining high adjusted R squares, with the limitation that only a few variables (service, cleaning and check-in, and boarding) have a positive and significant relationship.

Table 4. Multiple regression analysis.

\begin{tabular}{|c|c|c|c|c|c|}
\hline \multicolumn{6}{|c|}{ Regression Analysis by Geographical Areas } \\
\hline \multirow[b]{2}{*}{ Model } & \multicolumn{2}{|c|}{$\begin{array}{l}\text { Unstandardized } \\
\text { Coefficients }\end{array}$} & \multirow{2}{*}{$\begin{array}{c}\text { Standardized } \\
\text { Coefficients }\end{array}$} & \multirow[t]{2}{*}{$\mathbf{t}$} & \multirow[t]{2}{*}{ Sig. } \\
\hline & B & Std. Error & & & \\
\hline \multicolumn{6}{|c|}{ All airline companies, dependent variable: value (adjusted $R$ square $=0.761$ ) } \\
\hline (Constant) & -0.031 & 0.197 & & -0.161 & 0.872 \\
\hline Space for legs & 0.125 & 0.119 & 0.119 & 1050 & 0.295 \\
\hline Service & 0.189 & 0.089 & 0.217 & 2113 & 0.036 \\
\hline Cleanliness & 0.236 & 0.106 & 0.213 & 2224 & 0.027 \\
\hline Food and drink & -0.005 & 0.052 & -0.006 & -0.099 & 0.921 \\
\hline Comfort of seats & 0.156 & 0.148 & 0.133 & 1054 & 0.293 \\
\hline Check-in and boarding & 0.327 & 0.103 & 0.331 & 3157 & 0.001 \\
\hline Entertainment & -0.057 & 0.036 & -0.088 & -1548 & 0.123 \\
\hline
\end{tabular}


Table 4. Cont.

\begin{tabular}{|c|c|c|c|c|c|}
\hline \multicolumn{6}{|c|}{$\begin{array}{l}\text { Airline companies of the United States and Canada, dependent variable: value } \\
\text { (adjusted } \mathrm{R} \text { square }=0.788 \text { ) }\end{array}$} \\
\hline \multirow[b]{2}{*}{ Model } & \multicolumn{2}{|c|}{$\begin{array}{l}\text { Unstandardized } \\
\text { coefficients }\end{array}$} & \multirow{2}{*}{$\begin{array}{c}\text { Standardized } \\
\text { coefficients }\end{array}$} & \multirow[t]{2}{*}{$\mathbf{t}$} & \multirow[t]{2}{*}{ Sig. } \\
\hline & B & Std. error & & & \\
\hline (Constant) & -0.461 & 0.404 & & -1138 & 0.264 \\
\hline Space for legs & 0.313 & 0.330 & 0.311 & 0.948 & 0.351 \\
\hline Service & 0.168 & 0.196 & 0.176 & 0.855 & 0.399 \\
\hline Cleanliness & 0.778 & 0.337 & 0.644 & 2308 & 0.028 \\
\hline Food and drink & 0.037 & 0.079 & 0.053 & 0.467 & 0.643 \\
\hline Comfort of seats & -0.190 & 0.440 & -0.170 & -0.431 & 0.669 \\
\hline Check-in and boarding & -0.011 & 0.282 & -0.011 & -0.040 & 0.968 \\
\hline Entertainment & -0.030 & 0.070 & -0.041 & -0.426 & 0.673 \\
\hline \multicolumn{6}{|c|}{ Airline companies of Europe, dependent variable: value (adjusted R square $=0.788$ ) } \\
\hline (Constant) & 0.139 & 0.398 & & 0.349 & 0.728 \\
\hline Space for legs & 0.226 & 0.182 & 0.240 & 1246 & 0.219 \\
\hline Service & 0.383 & 0.165 & 0.421 & 2320 & 0.025 \\
\hline Cleanliness & 0.110 & 0.165 & 0.105 & 0.663 & 0.510 \\
\hline Food and drink & -0.072 & 0.142 & -0.093 & -0.510 & 0.612 \\
\hline Comfort of seats & 0.298 & 0.237 & 0.262 & 1257 & 0.215 \\
\hline Check-in and boarding & 0.067 & 0.208 & 0.061 & 0.323 & 0.748 \\
\hline Entertainment & -0.074 & 0.068 & -0.141 & -11012 & 0.277 \\
\hline \multicolumn{6}{|c|}{$\begin{array}{l}\text { Airline companies of other countries of America, dependent variable: value } \\
\text { (adjusted R square }=0.800 \text { ) }\end{array}$} \\
\hline (Constant) & 0.076 & 0.345 & & 0.222 & 0.824 \\
\hline Space for legs & 0.172 & 0.235 & 0.143 & 0.730 & 0.469 \\
\hline Service & 0.203 & 0.156 & 0.239 & 1298 & 0.201 \\
\hline Cleanliness & 0.074 & 0.176 & 0.067 & 0.423 & 0.674 \\
\hline Food and drink & 0.007 & 0.107 & 0.008 & 0.070 & 0.944 \\
\hline Comfort of seats & -0.060 & 0.263 & -0.045 & -0.230 & 0.818 \\
\hline Check-in and boarding & 0.637 & 0.187 & 0.614 & 3404 & 0.001 \\
\hline Entertainment & -0.099 & 0.090 & -0.115 & -1100 & 0.277 \\
\hline \multicolumn{6}{|c|}{ Regression analysis by low-cost or non-low-cost strategy } \\
\hline \multicolumn{6}{|c|}{ Low-cost airlines (adjusted R square $=0.832$ ) } \\
\hline & \multicolumn{2}{|c|}{$\begin{array}{l}\text { Unstandardized } \\
\text { coefficients }\end{array}$} & $\begin{array}{l}\text { Standardized } \\
\text { coefficients }\end{array}$ & $\mathbf{t}$ & Sig. \\
\hline Model & B & Std. error & Beta & & \\
\hline (Constant) & 0.012 & 0.221 & & 0.054 & 0.956 \\
\hline Space for legs & 0.078 & 0.153 & 0.073 & 0.509 & 0.611 \\
\hline Service & 0.398 & 0.113 & 0.451 & 3.519 & 0.001 \\
\hline Cleanliness & 0.158 & 0.127 & 0.146 & 1.238 & 0.219 \\
\hline Food and drink & -0.073 & 0.073 & -0.090 & -1.007 & 0.317 \\
\hline Comfort of seats & 0.202 & 0.193 & 0.166 & 1.050 & 0.297 \\
\hline Check-in and boarding & 0.273 & 0.127 & 0.271 & 2.152 & 0.034 \\
\hline Entertainment & -0.067 & 0.054 & -0.086 & -1.243 & 0.218 \\
\hline
\end{tabular}


Table 4. Cont.

\begin{tabular}{|c|c|c|c|c|c|}
\hline \multicolumn{6}{|c|}{ Non-low-cost airlines (adjusted $\mathrm{R}$ square $=\mathbf{0 . 6 6 2}$ ) } \\
\hline \multirow[b]{2}{*}{ Model } & \multicolumn{2}{|c|}{$\begin{array}{l}\text { Unstandardized } \\
\text { coefficients }\end{array}$} & \multirow{2}{*}{$\begin{array}{c}\text { Standardized } \\
\text { coefficients }\end{array}$} & \multirow[t]{2}{*}{$\mathbf{t}$} & \multirow[t]{2}{*}{ Sig. } \\
\hline & B & Std. error & & & \\
\hline (Constant) & -0.668 & 0.408 & & -1.636 & 0.107 \\
\hline Space for legs & 0.214 & 0.183 & 0.185 & 1.167 & 0.248 \\
\hline Service & 0.058 & 0.158 & 0.059 & 0.368 & 0.713 \\
\hline Cleanliness & 0.232 & 0.179 & 0.185 & 1299 & 0.199 \\
\hline Food and drink & 0.023 & 0.072 & 0.031 & 0.319 & 0.750 \\
\hline Comfort of seats & 0.168 & 0.229 & 0.135 & 0.733 & 0.466 \\
\hline Check-in and boarding & 0.475 & 0.174 & 0.460 & 2.729 & 0.008 \\
\hline Entertainment & -0.035 & 0.053 & -0.062 & -0.658 & 0.513 \\
\hline
\end{tabular}

With regard to the regression carried out with all the airlines together, the adjusted $\mathrm{R}$ square was 0.761 . The variables that have a significant $(p<0.05)$ and positive relationship with the perceived value are "service", "cleanliness", and "check-in and boarding". The rest of the variables on the service quality scale are not related to the perceived value. This shows that the measurement of value by customers can be determined from the assessments made of the service received, the cleaning of the aircraft, and the passenger check-in and boarding processes. Therefore, these three attributes are critical for customers and have a relevant impact on the online reputation.

The group of European airlines achieved the lowest adjusted R square, with a value of 0.622 . Despite being the lowest result of all the regressions conducted, the value obtained is quite relevant in social sciences. Therefore, it can be stated that the model explains the relationship between the perceived service quality and the perceived value. Analyzing the level of significance of each variable on the service quality scale in greater detail, Table 4 shows that "service" is the only significant variable $(p<0.05)$. This result assumes that the value perceived by customers of European airlines is basically related to the service received, whereas the other variables are not significantly related.

For USA and Canadian airlines, the adjusted R square is very high at 0.788 . In this case, there is also only one variable from the quality of service scale that has a significant and direct relationship with the perceived value. This variable is cleanliness, which, with a level of significance of 0.03 and a coefficient of 0.78 , stands out as the main attribute that customers assess in perceived value.

Airlines from other American countries obtained the highest adjusted R square, with a value of 0.80. In this case, again, only one variable on the quality of service scale obtained a significant result. Unlike the other two groups analyzed, it was "check-in and boarding", which obtained a value of 0.637 with a significance level of 0.001 . The results obtained in the multiple regressions carried out show significant differences in the perceptions of airline users depending on the geographical areas in which they operate. Whereas customers in Europe mainly value the service provided by the airlines, users in the United States and Canada mainly consider the cleanliness of the aircraft, and customers in other American countries evaluate the check-in and boarding processes to a greater extent.

On the other hand, the regression conducted for airlines with a low-cost strategy obtained an adjusted $\mathrm{R}$ square of 0.832 , being directly and positively related to the perceived value the service $(p<0.01)$ and check-in and boarding $(p<0.05)$ variables. The rest of the airlines have obtained an adjusted $\mathrm{R}$ square of 0.662 , with check-in $(p<0.01)$ and boarding being the only variable that is directly and significantly related to the perceived value. In this case, the predictive validity of the TripAdvisor scale is also verified with the same limitation of the small number of significant variables. However, these variables are validated to perform the positioning analysis. 


\subsection{Positioning Analysis by Variables}

The positioning analysis carried out in this study is based on the elaboration of plots, where the airlines are fixed according to the scores obtained by pairs of variables [19]. The variable that is repeated in all the analyses is the perceived value, and so it is a key variable where service quality and price are related [57,87-89]. There are four other variables used in positioning. The first is the average quality of service $(Q)$, which, as previously specified in the methodology section, is obtained by calculating the average of the seven variables used to measure the perceived service quality on TripAdvisor. The other three variables were selected from the multiple regression analysis, where the variables that had a significant relationship with the perceived quality of service were identified: "service", "cleanliness", and "check-in and boarding".

Figure 2 depicts the four analyses conducted with regard to the average quality of service $(Q)$ and the perceived value. The first includes all airlines. In the remaining three, each of the three groups of airlines is analyzed individually. The first graph shows that there is a high concentration of customer ratings with respect to value. Thus, the minimum rating is 3 , whereas the maximum value given by customers is 4.5 . On the other hand, the online reputation of the average quality of service (Q) shows significant differences because some companies obtain a rating of less than 2 , whereas some almost reach the maximum value of 5 .

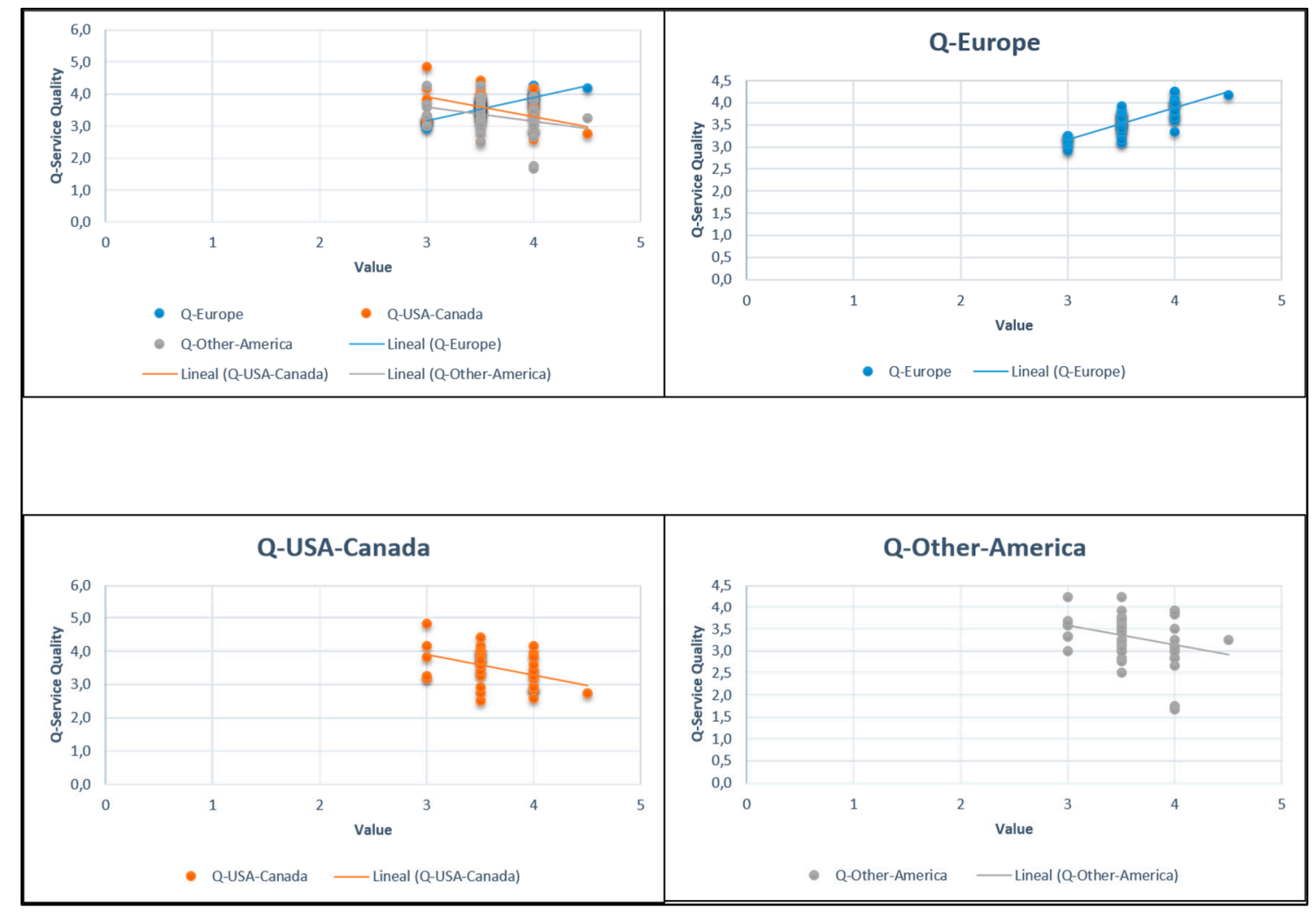

Figure 2. Positioning of airlines as a function of the value and service quality average (Q).

An analysis of the positioning by group of airlines by geographical areas shows that European airlines show less dispersion in the average quality of service $(\mathrm{Q})$. The minimum value is around 3 , whereas the highest value is 4.5. An increasing function is also observed; that is, the higher the perceived quality of service, the higher the value perceived by the customer. These data are of great interest because the perceived value tends to decrease as quality is offered [19].

In many cases, when companies increase their quality of service, they tend to increase the price. With this strategy, customers can decrease their perceived value because they can consider that the price increase is higher than the increase in the quality of the service offered $[35,90]$. In this case, 
the clients positively evaluate the increase in the quality of service in relation to what it costs them. This result demonstrates a high competitive capacity of European airlines, insofar as they transmit to their customers the benefits they receive for a reasonable price.

In the USA and Canada group, the results are more disperse because some airlines have an online reputation of 2.5, compared to others that almost reach the maximum score of 5 . This is a typical strategy of low-cost airlines, which significantly lower the price by reducing services. As Figure 2 shows, there are many customers in these areas who value this low-price strategy positively.

A similar situation is seen in airlines from other American countries, although the dispersion in the average quality of service $(\mathrm{Q})$ is somewhat greater. There is also evidence of customer recognition for lowering prices by reducing the quality of service offered. This strategy leads customers to give a higher score to the perceived value than to the average perceived quality of service $(Q)$. According to Rodríguez-Díaz et al. [19], this type of strategy normally obtains a positive added value.

The other three variables included in the positioning analysis showed a significant relationship with the perceived value. Figure 3 depicts the results of the "service" variable, which were significant for European airlines. These results confirm that European customers value the quality of the service offered positively, insofar as the function that explains the relationship between this variable and the perceived value is growing. This is not the case in the other two groups. In the USA and Canada markets, "cleanliness" is a differentiating element that shows a moderately decreasing function.

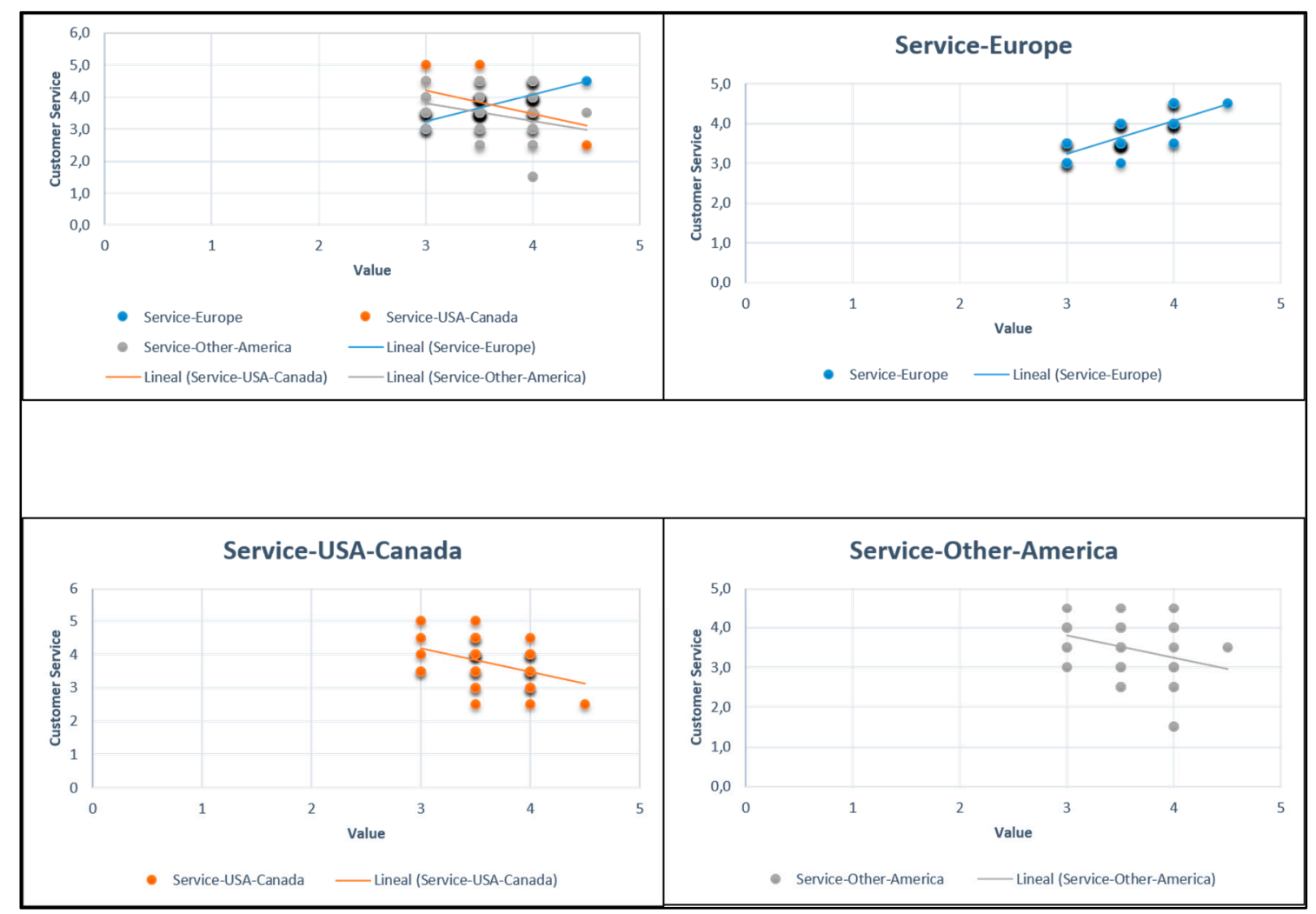

Figure 3. Positioning of airlines as a function of the value and service (geographical areas).

Figure 4 shows that the function begins at a value close to 4.5 and ends at a value close to 3.5, whereas in the group of other American countries, it begins at 4 and ends at 3.5. With regard to "check-in and boarding", Figure 5 shows that in Europe the trend continues to increase, whereas in the other two groups it is decreasing. Even though the slopes of the airlines from the USA and Canada and the other countries in America are similar, there is greater dispersion in the average in the latter group. This shows that a significant number of airlines have serious problems with this strategic aspect of service quality, obtaining a share of airline values equal to or less than 3 . 


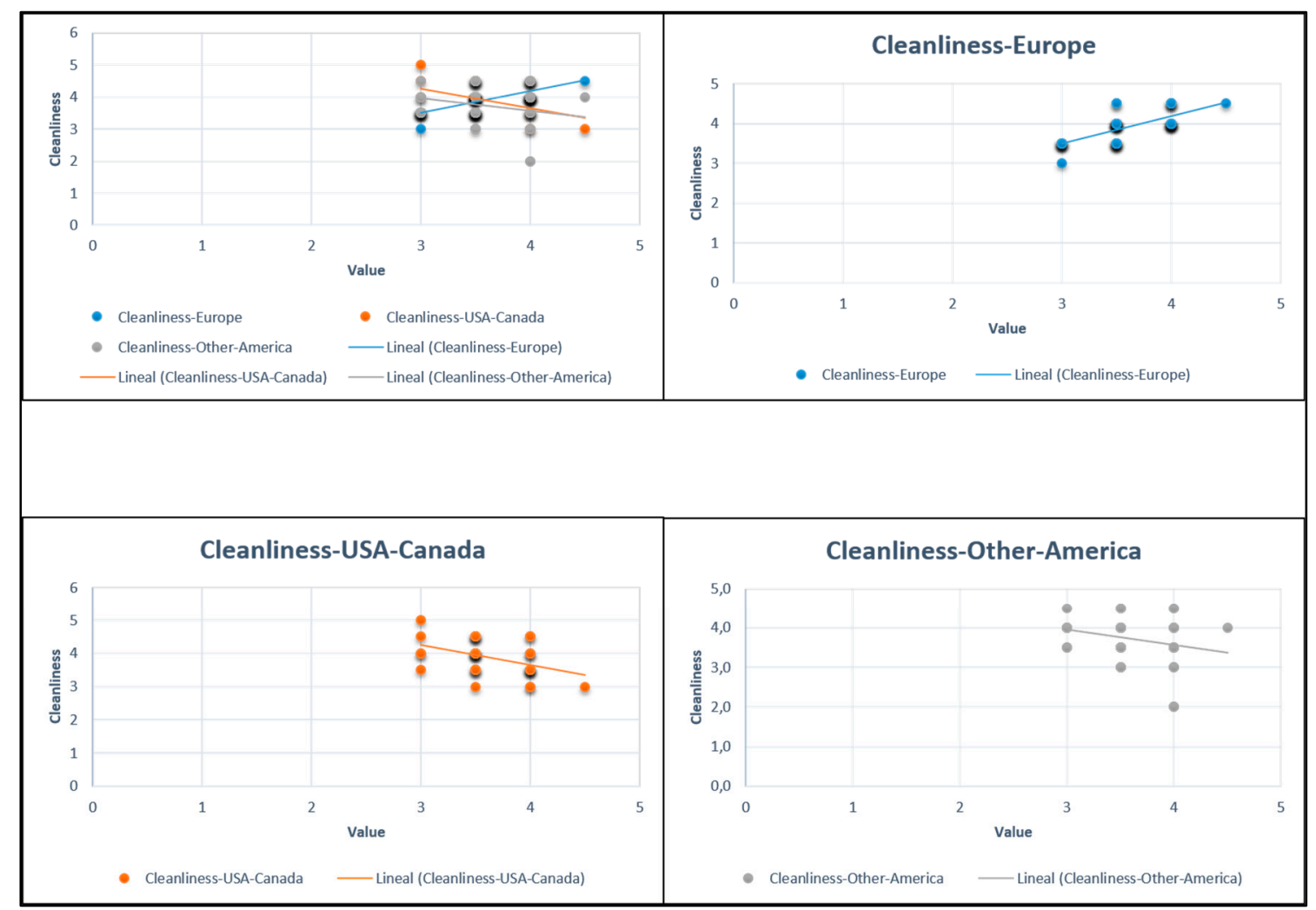

Figure 4. Positioning of airlines as a function of the value and cleanliness (geographical areas).

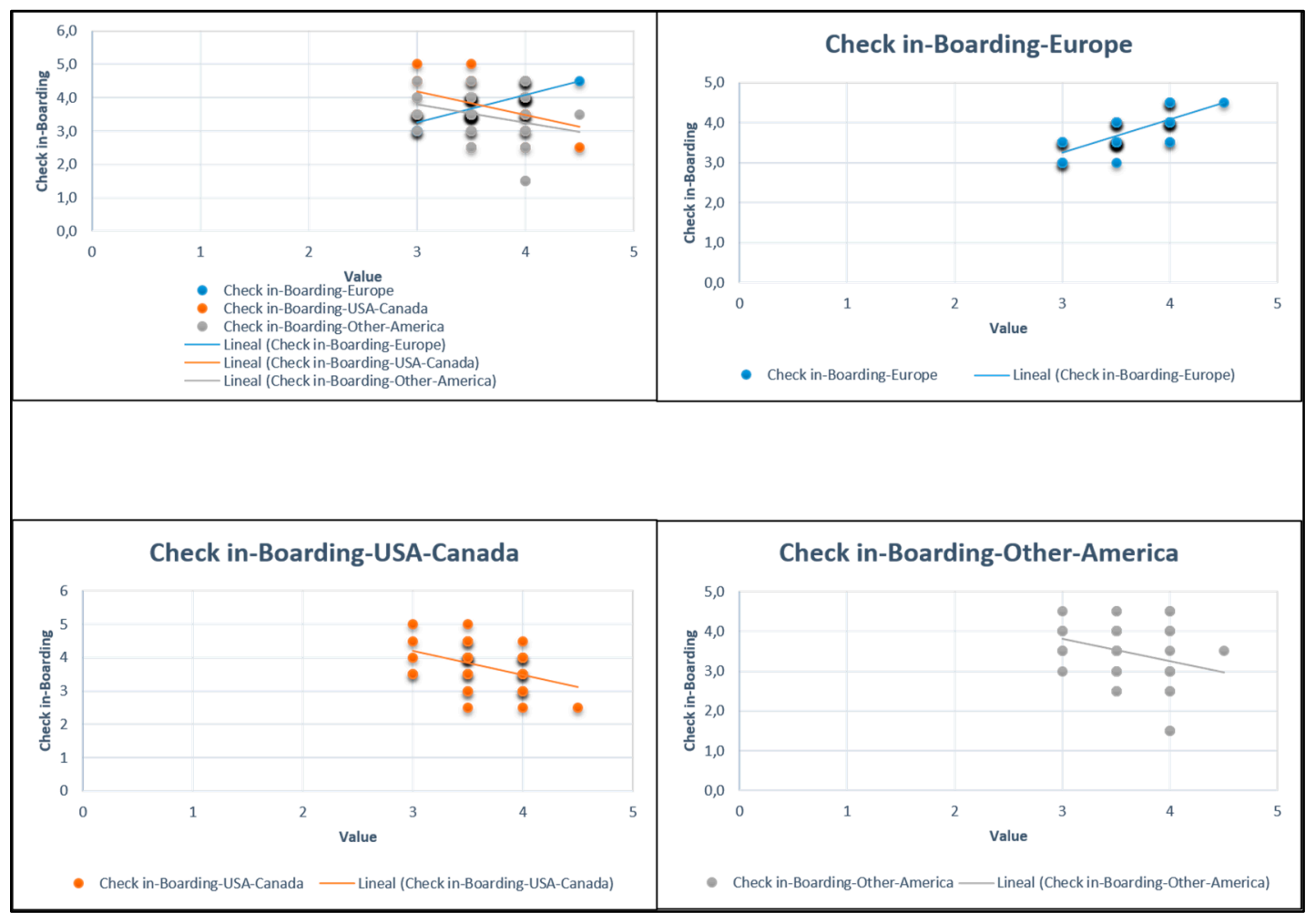

Figure 5. Positioning of airlines as a function of the value and check-in and boarding (geographical areas). 
Figure 6 shows the positioning analysis according to the airlines' strategy. With respect to the check-in and boarding variables, it can be seen that there are no significant differences between the low-cost airlines and the rest. Moreover, both groups follow an increasing function, whereas the low-cost airlines obtain the lowest values to a greater extent. Regarding service, this has only been performed for low-cost airlines because this variable is significant only in this group. Figure 6 shows that the function obtained is increasing. It starts with airlines that do not reach a score of 2 either in service or in perceived value, and reaches its maximum values with airlines that obtain scores up to 4.5 in service and value.

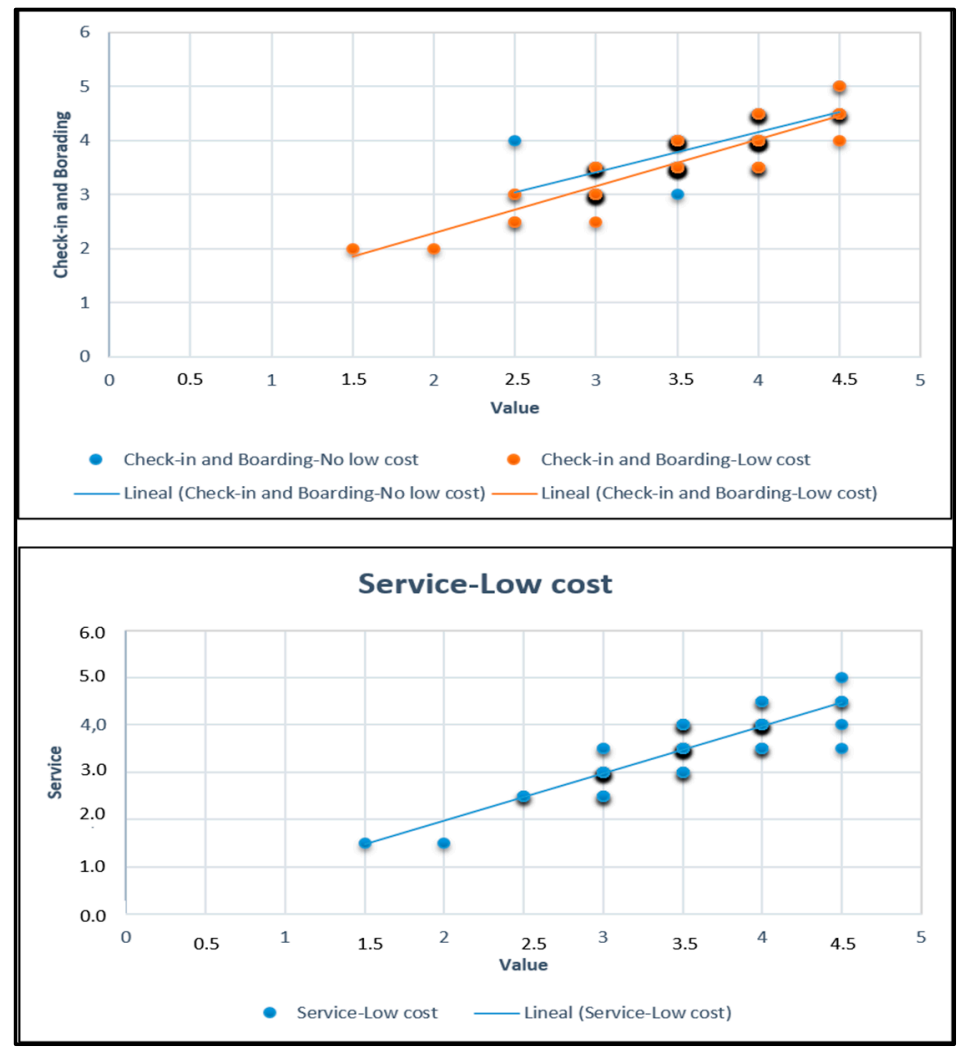

Figure 6. Positioning of airlines as a function of the value and check-in and boarding or service (low-cost or non-low-cost strategy).

\subsection{Positioning by Regression Analysis}

The positioning analysis is obtained through a bivariate regression between the perceived value and the perceived service quality factor. This method has the advantage that it is possible to determine the type of function that best defines the relationship between the dimensions analyzed. This has strong practical implications because each company can determine its competitive positioning from its own evaluations of its online reputation as well as that of its competitors. However, there has to be a significant relationship between the dimensions analyzed in order for the results to be reliable.

Therefore, bivariate regressions were carried out in order to analyze the type of function that best matches the relationship between perceived service quality and perceived value. In order to perform this statistical analysis, the perceived value was used as the variable to be explained, whereas the dependent variable was the factorial load saved in the factorial analysis. Table 5 presents the results obtained for airlines grouped by geographical areas, highlighting the adjusted R square of 0.700 for linear, quadratic, and cubic regressions, whereas the inverse function, with an adjusted $R$ square of 0.002 , does not explain the relationship between the dimensions studied. 
Table 5. Positioning by regressions with value as dependent variable and service quality factor as independent variable (geographical areas).

\begin{tabular}{|c|c|c|c|c|c|c|c|c|c|}
\hline \multirow{2}{*}{ Equation } & \multicolumn{5}{|c|}{ Model Summary } & \multicolumn{4}{|c|}{ Parameter Estimates } \\
\hline & R Square & $\mathbf{F}$ & df1 & df2 & Sig. & Constant & b1 & b2 & b3 \\
\hline \multicolumn{10}{|c|}{ All airline companies } \\
\hline Linear & 0.694 & 312.382 & 1 & 138 & 0.000 & 3.546 & 0.441 & & \\
\hline Inverse & 0.002 & 0.303 & 1 & 138 & 0.583 & 3.549 & 0.002 & & \\
\hline Quadratic & 0.700 & 159.612 & 2 & 137 & 0.000 & 3.571 & 0.426 & -0.025 & \\
\hline Cubic & 0.700 & 105.770 & 3 & 136 & 0.000 & 3.575 & 0.435 & -0.030 & -0.003 \\
\hline \multicolumn{10}{|c|}{ Airline companies from Europe } \\
\hline Linear & 0.578 & 65.652 & 1 & 48 & 0.000 & 3.485 & 0.401 & & \\
\hline Inverse & 0.015 & 0.718 & 1 & 48 & 0.401 & 3.581 & 0.005 & & \\
\hline Quadratic & 0.578 & 32.217 & 2 & 47 & 0.000 & 3.478 & 0.394 & 0.016 & \\
\hline Cubic & 0.578 & 21.022 & 3 & 46 & 0.000 & 3.477 & 0.397 & 0.019 & -0.003 \\
\hline \multicolumn{10}{|c|}{ Airline companies from the United States and Canada } \\
\hline Linear & 0.754 & 104.444 & 1 & 34 & 0.000 & 3.586 & 0.472 & & \\
\hline Inverse & 0.000 & 0.000 & 1 & 34 & 0.994 & 3.597 & $-8.956 \mathrm{E}-05$ & & \\
\hline Quadratic & 0.761 & 52.491 & 2 & 33 & 0.000 & 3.631 & 0.473 & -0.036 & \\
\hline Cubic & 0.762 & 34.201 & 3 & 32 & 0.000 & 3.621 & 0.508 & -0.028 & -0.013 \\
\hline \multicolumn{10}{|c|}{ Airline companies from other countries in America } \\
\hline Linear & 0.728 & 120.708 & 1 & 45 & 0.000 & 3.626 & 0.484 & & \\
\hline Inverse & 0.000 & 0.016 & 1 & 45 & 0.900 & 3.460 & 0.001 & & \\
\hline Quadratic & 0.737 & 61.668 & 2 & 44 & 0.000 & 3.646 & 0.433 & -0.030 & \\
\hline Cubic & 0.741 & 41.068 & 3 & 43 & 0.000 & 3.677 & 0.456 & -0.076 & -0.015 \\
\hline
\end{tabular}

Analyzing the results according to the groups of airlines, it can be seen that European airlines obtain the lowest adjusted R square, 0.578 for the linear, quadratic, and cubic functions, whereas the inverse is not a model that can be applied. The airlines from the USA and Canada increase their adjusted $R$ square to 0.754 in the linear function, 0.761 in the quadratic function, and 0.762 in the cubic function. The result for the inverse function was 0.000 ; that is, it is not a useful model for determining the relationship between the variables studied.

Finally, the airlines from the rest of the American countries also achieve very high results. The adjusted $\mathrm{R}$ square for the linear function was $0.728,0.737$ for the quadratic function, and 0.741 for the cubic function. The inverse function again shows no significant relationships between the variables. As can be observed in the previous regressions, any of the three functions can be used to determine the relationship between the perceived quality of the service and the perceived value because they all have similar results. This can be verified in Figure 7, where the analyzed functions are graphically displayed, verifying that they practically form a straight line. 


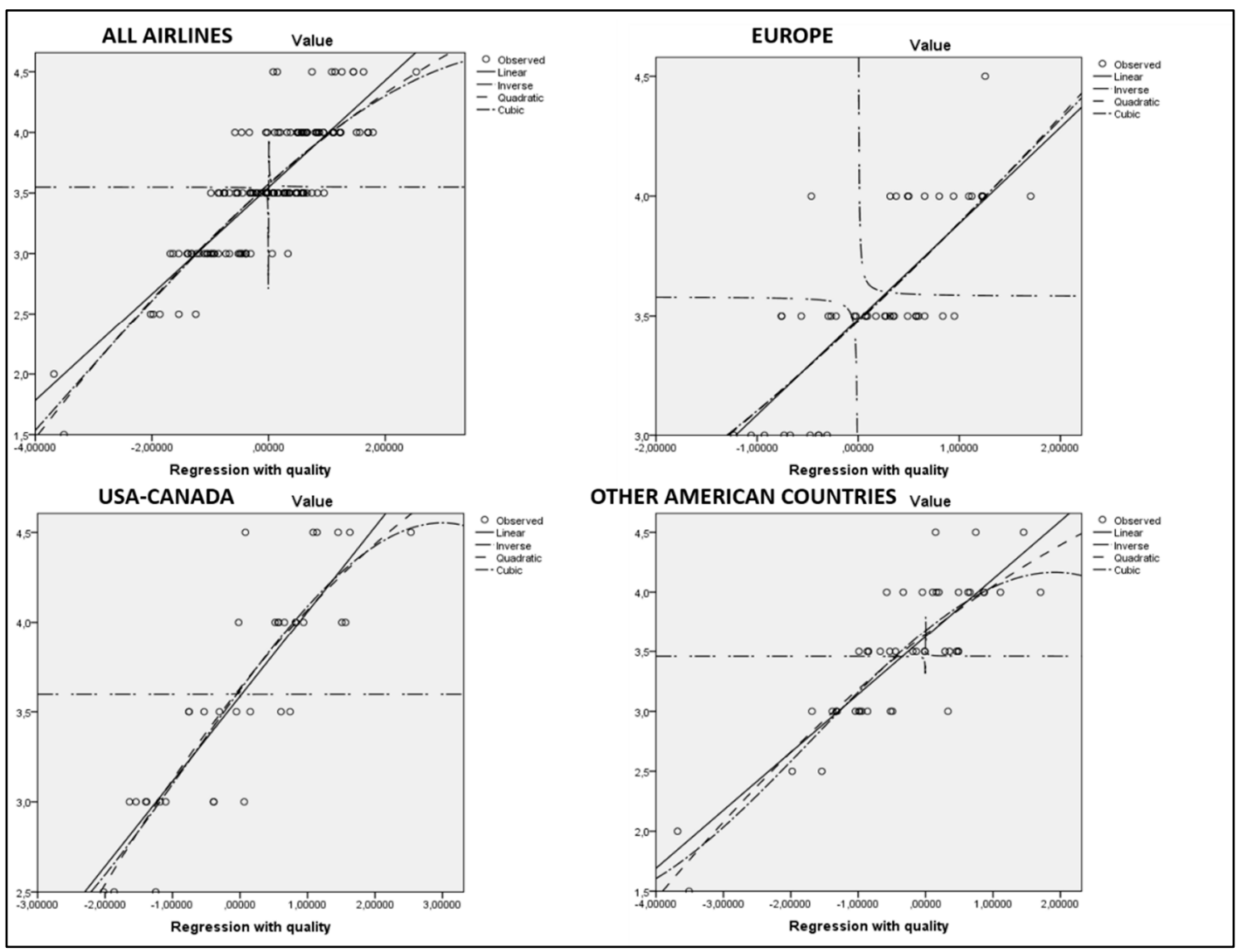

Figure 7. Plots of positioning by regression analysis (geographical areas).

These results demonstrate that the relationship between the variables studied is linear and increasing for airlines grouped by geographical areas; that is, while the quality of the service perceived by the client increases, the perceived value also increases, practically in the same proportion. The statistical analyses carried out verify the relationship between the two constructs studied and predicted in the literature review $[52,63,64,67]$. At the same time, the validity of predicting the value perceived by customers based on their ratings on the scale of perceived service quality is confirmed $[19,20]$.

Table 6 shows the results obtained in positioning by regression according to the strategy of the airlines. It can be seen that low-cost companies obtain very high adjusted R-squares in the linear (0.782), quadratic (0.797), and cubic (0.799) functions. On the other hand, the analysis of the companies that do not follow this strategy has been carried out separately for each of the two factors. With regard to factor 1 , it was verified that it is not related to the perceived value, since adjusted R-squares are very low, less than 0.20 . On the contrary, in the second factor, which integrates the check-in and boarding, service and cleanliness variables, the adjusted R-squares reach the value of 0.564 in the linear function, 0.570 in the quadratic, and 0.572 in the cubic.

Analyzing Figure 8, it can be seen that low-cost airlines have a positioning that follows an increasing linear function, due to the fact that quadratic and cubic functions are overlapping the linear one. On the other hand, the factor 1 of the quality of the service of the airlines that are not low-cost obtains functions that hardly differentiate the positioning of the companies. The contrary situation is obtained in factor 2 of the perceived service quality, where the functions practically coincide again with the increasing linear function. 
Table 6. Positioning by regressions with value as dependent variable and service quality factors as independent variable (low-cost or non-low-cost strategy).

\begin{tabular}{|c|c|c|c|c|c|c|c|c|c|}
\hline \multirow{2}{*}{ Equation } & \multicolumn{5}{|c|}{ Model Summary } & \multicolumn{4}{|c|}{ Parameter Estimates } \\
\hline & R Square & $\mathbf{F}$ & df1 & df2 & Sig. & Constant & b1 & b2 & b3 \\
\hline \multicolumn{10}{|c|}{ Low-cost airline companies } \\
\hline Linear & 0.782 & 269.331 & 1 & 75 & 0.000 & 3.487 & 0.517 & & \\
\hline Inverse & 0.007 & 0.565 & 1 & 75 & 0.454 & 3.482 & -0.001 & & \\
\hline Quadratic & 0.797 & 145.371 & 2 & 74 & 0.000 & 3.530 & 0.504 & -0.044 & \\
\hline Cubic & 0.799 & 96.799 & 3 & 73 & 0.000 & 3.538 & 0.537 & -0.054 & -0.009 \\
\hline \multicolumn{10}{|c|}{ Non-low-cost airline companies (factor 1 ) } \\
\hline Linear & 0.120 & 8.318 & 1 & 61 & 0.005 & 3.619 & 0.154 & & \\
\hline Inverse & 0.012 & 0.748 & 1 & 61 & 0.390 & 3.612 & -0.000 & & \\
\hline Quadratic & 0.144 & 5.051 & 2 & 60 & 0.009 & 3.580 & 0.195 & 0.038 & \\
\hline Cubic & 0.172 & 4.102 & 3 & 59 & 0.010 & 3.546 & 0.108 & 0.105 & 0.029 \\
\hline \multicolumn{10}{|c|}{ Non-low-cost airline companies (factor 2 ) } \\
\hline Linear & 0.564 & 79.137 & 1 & 61 & 0.000 & 3.619 & 0.335 & & \\
\hline Inverse & 0.005 & 0.344 & 1 & 61 & 0.559 & 3.615 & -0.002 & & \\
\hline Quadratic & 0.570 & 39.858 & 2 & 60 & 0.000 & 3.589 & 0.327 & 0.030 & \\
\hline Cubic & 0.572 & 26.325 & 3 & 59 & 0.000 & 3.594 & 0.295 & 0.021 & 0.014 \\
\hline
\end{tabular}

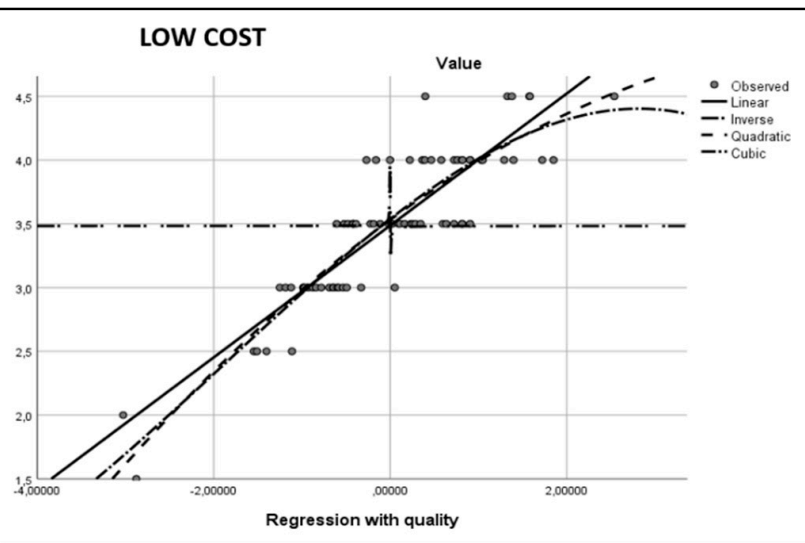

NO LOW COST FACTOR 1

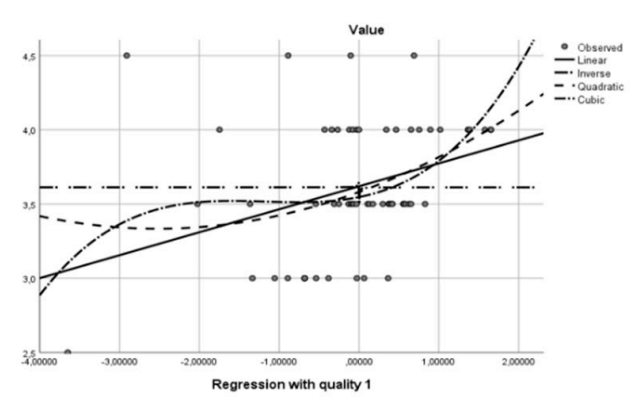

NO LOW COST FACTOR 2

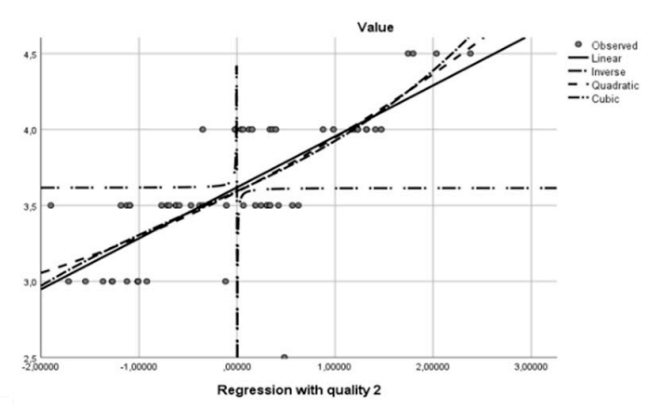

Figure 8. Plots of positioning by regression analysis (low-cost or non-low-cost strategy). 


\section{Discussion}

The study carried out demonstrates the suitability of the proposed methodology for analyzing the online reputation and positioning of airlines. Likewise, it proves to be useful for both airline managers and research on online customer ratings. Regarding the online reputation defined from the scale of variables used by TripAdvisor, the results verify that it obtains information on two constructs: the perceived quality of the service and the perceived value. These results are similar to those obtained in other studies on hotels' online reputation that demonstrated differences between these two constructs [19,23-25]. It is important to determine that TripAdvisor's scale of variables measures these two constructs, in order for companies to be assured that the competitive and positioning studies conducted are supported by a solid theoretical framework.

Factorial analysis has verified the one-dimensional nature of the scale for measuring perceived service quality, which consists of seven variables, in airlines grouped by geographical areas and those that follow a low-cost strategy. These results were contrasted for all the airlines as a whole and for the three groups formed according to geographical location, on the one hand, and grouped by the low-cost or non-low-cost strategy, on the other. The reliability of this scale was also verified by obtaining high Cronbach's alphas. These results demonstrate that the online opinions expressed by customers were collected with a reliable statistical procedure and in accordance with the theoretical framework. In this context, other studies conducted in the hotel industry also confirmed that the perceived quality of service is usually measured on specialized websites such as TripAdvisor using scales of variables that make up a single factor $[19,23,25]$.

In relation to the perceived value, the results confirmed that, although it is measured with only one variable [45], it is quite useful in carrying out relevant statistical analyses to validate the scale used by TripAdvisor. Along these lines, multiple regression analyses demonstrated the close relationship between the perceived service quality and perceived value constructs $[55,67]$. To the extent that the variable to be explained was the perceived value, it can be concluded that perceived value can be predicted based on clients' assessments of the service quality variables.

When analyzing service quality variables that are significantly related to perceived value, different results are obtained in the regressions. When all the airlines in the sample are included, three significant variables are obtained: "service", "cleanliness", and "check-in and boarding". However, when the regression is carried out individually for each of the zones, it is possible to verify that for the European clients the only variable related to the perceived value is the service received. Customers in the USA and Canada value cleanliness as the main dimension linked to perceived value, whereas for users in the other countries in America, the procedures followed by airlines to check in and board aircraft are most related to the value they perceive. With regard to the strategy followed by the airlines, it was found that low-cost airlines obtain significant relationships in the service and check-in and boarding variables, while non-low-cost airlines only have check-in and boarding as the only variable significantly related to the perceived value of the customers.

This result is highly significant for analyzing the strategy and competitive positioning that airlines must apply depending on the market they select. It shows that customers have different perceptions in each market and, more importantly, that only some key aspects of service quality influence the perceived value. For example, the leg room between seats, the comfort of the seats, entertainment on the plane, or food and drink are not aspects that customers differentiate in the perceived value of airlines. This may be because many companies do not discriminate in these aspects. By contrast, service in a generic sense, cleanliness, and the time needed for check-in and boarding, as well as possible flight delays, determine customers' ratings of perceived value to a greater extent.

The positioning analysis was also successful from the perspective of practitioners and research. The first aspect that stands out from the graphs drawn up is that trends by geographical groups are different when service quality is analyzed in relation to value. Whereas in European airlines the trend is increasing, i.e., the higher the quality of service perceived by the customer, the greater the value perceived in the airline, in the other two groups the opposite trend is taking place. 
The positioning by regressions revealed that the relationship between the perceived value and the perceived service quality factor is increasing almost linearly in any of the functions analyzed. The linear, quadratic, and cubic functions obtained adjusted $R$ squares above 0.6 , demonstrating very robust models. These results were achieved in the joint regression analysis of all the airlines and in the analyses performed individually for each group of companies. The graphical representation of the functions makes it possible to visually check how the lines of the three functions are practically confused with the linear function. Therefore, the airlines' clients increase their ratings of the perceived value as they increase their ratings of the perceived quality of the service. The only exception is the one obtained by factor 1 of the quality of service perceived by the airlines that do not follow a low-cost strategy, which did not discriminate between the variables assigned and the value perceived. Therefore, it cannot be used to analyze the competitive positioning of the airlines. This is not the case with factor 2 of the quality of service, which fits an increasing linear function.

These results may contradict those obtained in online reputation research in the hotel sector, to the extent that when the quality of a hotel's service increases, the customer may perceive that the price increase is greater than the improvement in quality. This often leads customers to score the value below the quality of service perceived $[19,35,90]$. The results obtained have great practical implications, because by demonstrating that there is a linear relationship between the perceived value and the perceived service quality factor, companies will be able to easily determine their positioning if they know their online reputation. They will also be able to easily establish time positioning objectives or repositioning strategies.

Another aspect to highlight is that the analyses carried out show that including the value construct in the measurement scales of online reputation is quite useful in the study of positioning. From this perspective, it can be said that online reputation scales should take this circumstance into account, as Rodríguez-Díaz and Espino-Rodríguez [23] pointed out in the hotel sector. It is important to keep in mind that the number of variables that users are willing to rate on specialized websites is limited. Therefore, it is essential for the scales to incorporate key variables to conduct statistical and strategic studies.

This study shows that both objectives have been achieved. On the one hand, a methodology for the competitive positioning of companies and brands based on their online reputation has been proposed and validated. On the other hand, this methodology has been applied to the airline sector, obtaining the variables to be used to perform the positioning analysis (service, cleaning and check-in, and boarding). It is also shown that the quality factors obtained, although not all the variables are significant individually, also serve to position the airlines, except for factor 2 of the service quality of the non-low-cost airlines, since they obtain high adjusted R squares. This study represents a progress in this line of research because the steps to be followed are detailed in a specific methodology and, on the other hand, because it is applied to a sector different from the hotel sector with a scale to measure the quality of service with variables that are totally different from those used in tourist accommodation.

\section{Conclusions}

Marketing positioning is an essential aspect in defining an airline's strategy. Positioning studies have traditionally been carried out through complex empirical work, based on the assessments of potential customers. However, currently, the information available on the Internet facilitates the development of competitive positioning in a dynamic way. Customers often share their experiences and assessments of airlines, which generates an updated database of what users think, not only about a particular airline, but also about its competitors. This study proposes a methodology for positioning analysis based on online reputation with quantitative variables that consists of eight steps, which is validated with the empirical study.

With the information available on the Internet about the online reputation of airlines, as in the case of TripAdvisor, the problem lies in determining whether this information is reliable and valid for competitive analysis, such as positioning. First, whether or not the reliability and validity of the 
information is proven, it is a fact that users currently become informed through the Internet before acquiring goods or services, such as those related to tourism. Therefore, the information available on the Internet must be considered fundamental in defining the communication strategy of the airlines. Second, it is necessary to contrast the reliability and validity of the information, both for the airlines and for the users themselves. There must be some guarantee that the information available is truthful and useful for making individual or business decisions, which is the perspective of this study. Finally, it is necessary to determine the variables that are most suitable for carrying out the positioning analysis. In this context, the study identified the key variables to define the competitive strategies of airlines. It also shows that variables that are not significantly related to the value perceived by customers are not being decisive in the creation of the airlines' value offer.

Marketing positioning facilitates companies' differentiation in the market, and it is the mechanism for obtaining competitive advantages over time. Thus, differentiation from competitors must be based on aspects or attributes that are valuable to users, and, at the same time, these aspects should be difficult to imitate, at least in the short term. To the extent that competitive positioning is formulated from the position of a particular brand or product in the minds of its users with respect to its competitors, online reputation is a new way to obtain updated information about customer ratings. Therefore, a positioning analysis based on online reputation has a triple advantage. On the one hand, the large amount of information shared by customers through social media is important for the communication strategy and definition of the competitive positioning of airlines. Moreover, this information is constantly being updated, which allows longitudinal studies to be carried out on customer ratings in relation to competitors. Finally, positioning studies that use this methodology are methodologically much simpler and easier to carry out, with the possibility of updating them whenever needed.

This information was tested in order to establish whether it is reliable and valid for conducting studies on competitive positioning. In this context, the results obtained confirm that the scale of variables of perceived quality of service used by TripAdvisor to measure the online reputation of airlines is one-dimensional in all factor analyses except for the airlines that do not follow the low-cost strategy, where two factors of perceived service quality were obtained. All the factors identified obtained a high Cronbach's Alpha. This means that all the variables on the scale are intimately related to each other, measuring a single construct. In the same way, the study verifies that the scale is reliable, that is, that the variables on the scale of perceived quality of service are related to each other. Another important aspect demonstrated in the study is that predictive validity is also tested, which provides scientific support for the use of the data for different studies such as competitive positioning.

The practical implications of the aspects demonstrated in the study are of great strategic importance for airlines. The positioning analysis was conducted based on a classification of airlines by geographical areas and by low-cost or non-low-cost strategies. It was shown that significant differences exist between key variables of the perceived service quality when they are related to the value perceived by customers, such as service, cleaning, and check-in and boarding. This means that positioning analysis based on the online reputation of airlines should be based on these quantitative variables, as they are the only ones directly related to the quality of service perceived by customers. Another aspect demonstrated in this study is that service quality factors can be used in regression positioning to carry out this type of strategic analysis, because, except for the factor 1 of non-low-cost airlines, they obtain a high adjusted $\mathrm{R}$ square. It should be pointed out that, despite the fact that only a few variables in the scale have a significant relationship with the perceived value, given that the regression models are so robustly adjusted, it can be said that they can also be used to conduct positioning analyses on airlines.

Another implication of this study is that online reputation offers a way to establish the degree of differentiation of marketing strategies from the perspective of customers. In addition, it can assess whether the airline differentiation strategy is maintained over time through longitudinal studies. By relating the variables on the scale of perceived service quality to the value perceived by customers, it is possible to establish which attributes are the most valuable for customers. This makes it possible to detect key variables to consolidate or reposition the competitive strategy of the airlines. 
This study achieves progress in this line of research with regard to the two objectives set. On the one hand, it has specified and defined the steps to be followed in the methodology to carry out the positioning analysis of airlines according to their online reputation. This means theoretically and practically reinforcing this type of strategic study in relation to previous research undertaken in this same line. On the other hand, it has been applied to the airline sector, where the scales of quantitative measurement are different from those of tourist accommodation. Much more, the line of research is also extended by confirming the usefulness of quantitative variables of online reputation for conducting competitive positioning analyses in a sector that has not been studied from this specific perspective until now, such as airlines. Despite the fact that this study is carried out with quantitative variables, there is the possibility of carrying out comparative studies between airlines according to the satisfaction extracted in the qualitative comments of the clients online. However, a positioning analysis on this type of variables would require the development of new methodologies in order to specify as accurately as possible the differences or similarities between the airlines according to each of the dimensions identified. One aspect to specify would be the method to be used to test when there is a significant difference between airlines with respect to a specific dimension of satisfaction.

Finally, it is important to emphasize the main limitations of this study. On the one hand, due to the scarce number of variables, statistical analyses are limited. In the airline sector, it is much more difficult to obtain additional information on the price or category of airlines than in the hotel sector. The availability of such variables could lead to partial least squares (PLS) analyses that would help to increase the study of the validity of the TripAdvisor online reputation scale. Another aspect to consider is that the study has focused on a sample of airlines and can be carried out in other geographical areas, segments or strategies. A further limitation is that websites specialized in assessing airline services are more limited than in other sectors such as hotels. For example, Booking and HolidayCheck do not offer ways for the user to rate airlines. This also limits comparative analyses to assess the validity of the scales. However, the positioning studies that airlines normally need usually focus on the most important and direct competitors, in order to constantly assess the evolution of the online reputation. From this perspective, more specific studies should be carried out where airlines establish their main competitors, in order to develop more precise and in-depth studies.

Another limitation is found in the positioning regression analysis, where the perceived service quality factor is used. Although a high adjusted square $\mathrm{R}$ is obtained, not all the variables on the perceived service quality scale have a significant relationship with perceived value. It is possible that by analyzing groups of more specific airlines, selected with criteria that better define the main competitors, other significant variables may be obtained. However, the most important thing is to verify a significant relationship between the variables used for the positioning, which is demonstrated with the adjusted R square. Despite this limitation, the study demonstrates that regression positioning is useful for airlines because it simplifies studies about their position, compared to competitors, from the perspective of customers who share their opinions on the Internet.

Author Contributions: The contribution from the authors to the current paper were as follows: conceptualization, A.Z.A. and M.R.-D.; methodology, A.Z.A.; software, M.R.-D.; investigation and validation, A.Z.A. and M.R.-D.; data curation, A.Z.A.; writing-original draft preparation, A.Z.A. and M.R.-D.; writing-review and editing, A.Z.A. and M.R.-D. All authors have read and agreed to the published version of the manuscript.

Funding: This research received no external funding.

Conflicts of Interest: The authors declare no conflict of interest.

\section{References}

1. Chun, R. Corporate reputation: Meaning and measurement. Int. J. Manag. Rev. 2005, 7, 91-109. [CrossRef]

2. Hernández Estárico, E.; Fuentes Medina, M.; Morini Marrero, S. Una aproximación a la reputación en línea de los establecimientos hoteleros españoles. Pap. De Tur. 2012, 52, 63-88.

3. Horster, E.; Gottschalk, C. Computer-assisted webnography: A new approach to online reputation management in tourism. J. Vacat. Mark. 2012, 18, 229-238. [CrossRef] 
4. Mudambi, S.M.; Schuff, D. What makes a helpful review? A study of customer reviews on Amazon.com. Mis Q. 2010, 34, 185-200. [CrossRef]

5. Yacouel, N.; Fleischer, A. The role of cybermediaries in reputation building and price premiums in the online hotel market. J. Travel Res. 2012, 51, 219-226. [CrossRef]

6. Gössling, S.; Hall, C.M.; Anderson, A.C. The manager's dilemma: A conceptualization of online review manipulation strategies. Curr. Issues Tour. 2016. Available online: http://www.tandfonline.com/doi/full/10. 1080/13683500.2015.1127337 (accessed on 15 September 2018).

7. Filieri, R.; McLeavy, F. E-WOM and accommodation an analysis of the factors that influence travelers' adoption of information from online reviews. J. Travel Res. 2014, 53, 44-57. [CrossRef]

8. Chen, Y.; Fay, S.; Wang, Q. The role of marketing in social media: How online consumer reviews evolve. J. Interact. Mark. 2011, 25, 85-94. [CrossRef]

9. Leung, D.; Law, R.; van Hoof, H.; Buhalis, D. Social media in tourism and hospitality: A literature review. J. Travel Tour. Mark. 2013, 30, 3-22. [CrossRef]

10. Chevalier, J.A.; Mayzlin, D. The effect of word of mouth on sales: Online book reviews. J. Mark. Res. 2006, 43, 345-354. [CrossRef]

11. Litvin, S.W.; Goldsmith, R.E.; Pan, B. Electronic word-of-mouth in hospitality and tourism management. Tour. Manag. 2008, 29, 458-468. [CrossRef]

12. Trusov, M.; Bucklin, R.E.; Pauwels, K. Effect of word-of-mouth versus traditional marketing: Findings from an Internet social networking site. J. Mark. 2009, 73, 90-102. [CrossRef]

13. Reyes-Menéndez, A.; Saura, J.R.; Martínez-Navalón, J.G. The impact of e-WOM on hotels management reputation: Exploring TripAdvisor review credibility with the ELM model. IEEE Access 2019, 7, 68868-68877. [CrossRef]

14. Hussain, S.; Ahmed, W.; Jafar, R.M.S.; Rabnawaz, A.; Jianzhou, Y. E-WOM source credibility, perceived risk and food product customer's information adoption. Comput. Hum. Behav. 2017, 66, 96-102. [CrossRef]

15. Li, H.; Ye, Q.; Law, R. Determinants of customer satisfaction in the hotel industry: An application of online review analysis. Asia Pac. J. Tour. Res. 2013, 18, 784-802. [CrossRef]

16. Park, S.Y.; Allen, J.P. Responding to online reviews: Problem solving and engagement in hotels. Cornell Hosp. Q. 2013, 54, 64-73. [CrossRef]

17. Rodriguez-Díaz, M.; Rodríguez-Voltes, C.I.; Rodríguez-Voltes, A.C. Gap analysis of the online reputation. Sustainability 2018, 10, 1603. [CrossRef]

18. Kotler, P.; Armstrong, G. Fundamentos de Marketing; Pearson Educación: Ciudad de México, Mexico, 2003.

19. Rodríguez Díaz, M.; Espino Rodríguez, T.F.; Rodríguez Díaz, R. A model of market positioning base on value creation and service quality in the lodging industry: An empirical application of online customer reviews. Tour. Econ. 2015, 21, 1273-1294. [CrossRef]

20. Vermeulen, I.E.; Seegers, D. Tried and tested: The impact of online hotel reviews on consumer consideration. Tour. Manag. 2009, 30, 123-127. [CrossRef]

21. Kim, W.G.; Lim, H.; Brymer, R.A. The effectiveness of managing social media on hotel performance. Int. J. Hosp. Manag. 2015, 44, 165-171. [CrossRef]

22. Lee, S.H.; Ro, H. The impact of online reviews on attitude changes: The differential effects of review attributes and consumer knowledge. Int. J. Hosp. Manag. 2016, 56, 1-9. [CrossRef]

23. Rodríguez-Díaz, M.; Espino-Rodríguez, T.F. Determining the reliability and validity of online reputation databases for lodging: Booking.com, TripAdvisror, and HolidayCheck. J. Vacat. Mark. 2018, 24, 261-274.

24. Rodríguez-Díaz, M.; Espino-Rodríguez, T.F. A methodology for a comparative analysis of the lodging tourism destinations based on online customer review. J. Destin. Mark. Manag. 2018, 8, 147-160. [CrossRef]

25. Ye, Q.; Li, H.; Wang, Z.; Law, R. The influence of hotel price on perceived service quality and value in e-tourism: An empirical investigation based on online traveller reviews. J. Hosp. Tour. Res. 2014, 38, $23-39$. [CrossRef]

26. Hooley, G.; Broderick, A.; Möller, K. Competitive positioning and the resource-based view of the firm. J. Strat. Mark. 1998, 6, 97-116. [CrossRef]

27. Lovelock, C. Services Marketing; Prentice Hall: Englewood Cliffs, NJ, USA, 1991.

28. Hung, W.T.; Shang, J.K.; Wang, F.C. Pricing determinants in the hotel industry: Quantile regression analysis. Int. J. Hosp. Manag. 2010, 29, 378-384. [CrossRef] 
29. Masiero, L.; Nicolau, J. Tourism market segmentation based on Price sensitivity: Finding similar price preferences on tourism activities. J. Travel Res. 2012, 51, 426-435. [CrossRef]

30. Gallarza, M.G.; Saura, I.G. Value dimensions, perceived value, satisfaction and loyalty: An investigation of university students' travel behaviour. Tour. Manag. 2006, 27, 437-452. [CrossRef]

31. Gallarza, M.G.; Gil-Saura, I.; Holbrook, M.B. The value of value: Further excursions on the meaning and role of customer value. J. Consum. Behav. 2011, 10, 179-191. [CrossRef]

32. Xie, K.L.; Zhang, Z.; Zhang, Z. The business value of online consumer reviews and management response to hotel performance. Int. J. Hosp. Manag. 2014, 43, 1-12. [CrossRef]

33. Hu, N.; Liu, L.; Zhang, J.J. Do online reviews affect product sales? The role of reviewer characteristics and temporal effects. Inf. Technol. Manag. 2008, 9, 201-214. [CrossRef]

34. Torres, E.N. Deconstructing service quality and customer satisfaction: Challenges and directions for future research. J. Hosp. Mark. Manag. 2014, 23, 652-677. [CrossRef]

35. O'Connor, P. Managing a hotel's image on TripAdvisor. J. Hosp. Mark. Manag. 2010, 19, 754-772. [CrossRef]

36. Dickinger, A.; Lalicic, L.; Mazanec, J. Exploring the generalizability of discriminat word items and latent topics in online tourist reviews. Int. J. Contemp. Hosp. Manag. 2017, 29, 803-816. [CrossRef]

37. Chi, G.G.; Gursoy, D. Employee satisfaction, customer satisfaction and financial performance: An empirical examination. Int. J. Hosp. Manag. 2009, 28, 245-253. [CrossRef]

38. Rodríguez-Díaz, M.; Rodríguez-Díaz, R.; Rodríguez-Voltes, A.C.; Rodríguez-Voltes, C.I. Analysing the relationship between price and online reputation by lodging category. Sustainability 2018, 10, 4474. [CrossRef]

39. Rodríguez-Díaz, M.; Rodríguez-Díaz, R.; Espino-Rodríguez, T.F. Analysis of the online reputation based on customer ratings of lodgings in tourism destinations. Adm. Sci. 2018, 8, 51. [CrossRef]

40. Rodríguez-Díaz, M.; Rodríguez-Voltes, C.I.; Rodríguez-Voltes, A.C. Determining the relationships between price and online reputation in lodgings. Adm. Sci. 2019, 9, 53. [CrossRef]

41. Rodríguez-Díaz, M.; Alonso-González, R.; Rodríguez-Voltes, C.I.; Rodríguez-Voltes, A.C. A rating of the online reputation balance in lodgings. Adm. Sci. 2019, 9, 58. [CrossRef]

42. Dijkmas, C.; Kerkhof, P.; Beukeboom, C.J. A stage to engage: Social media use and corporate reputation. Tour. Manag. 2015, 47, 58-67. [CrossRef]

43. Korfiatis, N.; Stamolpros, P.; Kourouthanassis, P.; Sagiadinos, V. Measuring service quality from unstructured data: A topic modeling application on airline passsegers' online reviews. Expert Syst. Appl. 2019, 116, 472-486. [CrossRef]

44. Stamolpros, P.; Korfiatis, N.; Kourouthanassis, P.; Symitsi, E. Flying to quality: Cultural influences on online reviews. J. Travel Res. 2019, 58, 496-511. [CrossRef]

45. Prebensen, N.K.; Woo, E.; Chen, J.S.; Uysal, M. Motivation and involvement as antecedents of the perceived value of the destination experience. J. Travel Res. 2012, 52, 253-264. [CrossRef]

46. Pantelidis, I.S. Electronic meal experience: A content analysis of online restaurant comments. Cornell Hosp. Q. 2010, 51, 483-491. [CrossRef]

47. Ryu, K.; Han, H. Influence of the quality of food, service, and physical environment on customer satisfaction and behavioural intention in quick-casual restaurants: Moderating role of perceived price. J. Hosp. Tour. Res. 2010, 34, 310-329. [CrossRef]

48. Zhang, Z.Q.; Ye, Q.; Law, R.; Li, Y.J. The impact of e-word-of-mouth on the online popularity of restaurant: A comparison of consumer reviews and editor reviews. Int. J. Hosp. Manag. 2010, 29, 694-700. [CrossRef]

49. Oliver, R.L. Satisfaction: A Behavioural Perspective on the Consumer; McGraw-Hill: New York, NY, USA, 1997.

50. Chadee, D.D.; Mattsson, J. An empirical assessment of customer satisfaction in tourism. Serv. Ind. J. 1996, 16, 305-320. [CrossRef]

51. Baker, D.A.; Crompton, J.L. Quality, satisfaction and behavioural intentions. Ann. Tour. Res. 2000, 27, 785-804. [CrossRef]

52. Füller, J.; Matzler, K.; Faullant, R. Asymmetric effects in customer satisfaction. Ann. Tour. Res. 2006, 33, 1159-1163. [CrossRef]

53. Nam, J.; Ekinci, Y.; Whyatt, G. Brand equity, brand loyalty and consumer satisfaction. Ann. Tour. Res. 2011, 38, 1009-1030. [CrossRef]

54. Einwiller, S. Vertrauen Durch Reputation im Elektronishech Handel. Ph.D. Thesis, University of St. Gallen, St. Gallen, Switzerland, 2003. 
55. Rust, R.T.; Oliver, R.L. Service quality: Insights and managerial implications from the frontier. In Service Quality: New Directions in Theory and Practice; Rust, R.T., Oliver, R.L., Oaks, T., Eds.; Sage Publications: Southend Oaks, CA, USA, 1994.

56. Parasuraman, A.; Zeithaml, V.; Berry, L.L. SERVQUAL: A multiple-item scale for measuring customer perceptions of service quality. J. Retail. 1988, 64, 12-40.

57. Oh, H. The effect of brand class, brand awareness, and price on customer value and behavioral intentions. J. Hosp. Tour. Res. 2000, 24, 136-162. [CrossRef]

58. Sparks, B.; Butcher, K.; Bradley, G. Dimensions and correlates of consumer value: An application to the timeshare industry. Int. J. Hosp. Manag. 2008, 27, 98-108. [CrossRef]

59. Nasution, H.N.; Mavondo, F.T. Customer value in the hotel industry: What managers believe they deliver and what customer experience. Int. J. Hosp. Manag. 2008, 27, 204-213. [CrossRef]

60. Núñez-Serrano, J.A.; Turrion, J.; Velázquez, F.J. Are stars a good indicator of hotel quality? Assymetric information and regulatory heterogeneity in Spain. Tour. Manag. 2014, 42, 77-87. [CrossRef]

61. Carman, J.M. Consumer perceptions of service quality: An assessment of the SERVQUAL dimensions. J. Retail. 1990, 66, 33-55.

62. Parasuraman, A.; Berry, L.L.; Zeithaml, V.A. Redefinement and reassessment of the SERVQUAL scale. J. Retail. 1991, 67, 420-450.

63. Parasuraman, A.; Berry, L.L.; Zeithaml, V.A. Alternative scales for measuring service quality: A comparative assessment based on pshchometric and diagnostic criteria. J. Retail. 1994, 70, 201-230. [CrossRef]

64. Babakus, E.; Boller, G.W. An empiricial assessment of the SERVQUAL scale. J. Bus. Res. 1992, 24, $253-268$. [CrossRef]

65. Brown, T.J.; Churchill, G.A., Jr.; Peter, J.P. Improving the measurement of service quality. J. Retail. 1993, 19, 127-139. [CrossRef]

66. Zeithaml, V.A. Consumer perceptions of price, quality, and value: A means-end model and synthesis of evidence. J. Mark. 1988, 52, 2-22. [CrossRef]

67. Holbrook, M.B. The nature of customer value: An axiology of services in the consumption experience. In Service Quality: New Directions in Theory and Practice; Rust, R.T., Oliver, R.L., Oaks, T., Eds.; Sage Publications: Southend Oaks, CA, USA, 1994.

68. Sweeney, J.C.; Soutar, G.N.; Johnson, L.W. The role of perceived risk in the quality-value relationship: A study in a retail environment. J. Retail. 1999, 75, 77-105. [CrossRef]

69. Bennett, R.; Kottasz, R. Practitioner perceptions of corporate reputation: An empirical investigation. Corp. Commun. 2000, 5, 224-235. [CrossRef]

70. Cobb-Walgren, C.J.; Ruble, C.A.; Donthu, N. Brand equity, brand preference, and purchase intent. J. Advert. 1995, 24, 25-40. [CrossRef]

71. Fombrun, C.; Shanley, M. What's in a name? Reputation building and corporate strategy. Acad. Manag. J. 1990, 33, 233-258.

72. Winters, L.C. The effect of brand advertising on company image-implications for corporate advertising. J. Advert. Res. 1986, 26, 54-59.

73. Okazaki, S.; Taylor, C.R. Social media and international advertising: Theoretical challenges and future directions. Int. Mark. Rev. 2013, 30, 56-71. [CrossRef]

74. Gray, E.R.; Balmer, J.M.T. Managing corporate image and corporate reputation. Long Range Plan. 1998, 31, 695-702. [CrossRef]

75. Sageder, M.; Mitter, C.; Feldbauer-Durstmüller, B. Image and reputation of family firms: A systematic literature review of the state of research. Rev. Manag. Sci. 2018, 12, 335-377. [CrossRef]

76. Chen, Y.S. The drivers of green brand equity: Green brand image, green satisfaction, and green trust. J. Bus. Ethics 2010, 93, 307-319. [CrossRef]

77. Lin, Y.; Ryan, C. From mission statement to airline branding. J. Air Transp. Manag. 2016, 53, $150-160$. [CrossRef]

78. Liou, J.J.; Chuang, M.L. Evaluating corporate image and reputation using fuzzy MCDM approach in airline market. Qual. Quant. 2010, 44, 1079-1091. [CrossRef]

79. Wen, C.H.; Lai, S.C.; Yeh, W.Y. Segmentation and positioning analysis for international air travel market: Taipei-to-Tokyo route. Transp. Res. Rec. 2008, 2052, 46-53. [CrossRef] 
80. Lucini, F.R.; Tonetto, L.M.; Fogliatto, F.S.; Anzanello, M.J. Text mining approach to explore dimensions of airline customer satisfaction using online customer reviews. J. Air Transp. Manag. 2020, 83, 101760. [CrossRef]

81. Rodríguez-Díaz, M.; Rodríguez-Díaz, R.; Rodríguez-Voltes, A.C.; Rodríguez-Voltes, C.I. A model of market positioning of destinations based on online customer reviews of lodgings. Sustainability 2018, 10, 78. [CrossRef]

82. Rodríguez-Díaz, M.; Espino Rodríguez, T.F. Determining the sustainability factors and performance of a tourism destination from stakeholders' perspective. Sustainability 2016, 8, 951. [CrossRef]

83. Dou, W.; Zhou, N.; Lim, K.H.; Cui, N.; Su, C. Brand positioning strategy using search engine marketing. MIS Q. 2010, 34, 271-279. [CrossRef]

84. Sayman, S.; Hoch, S.J.; Raju, J.S. Positioning of store brands. Mark. Sci. 2002, 4, 378-397. [CrossRef]

85. Luca, M. Reviews, Reputation, and Revenue: The Case of Yelp.com; Harvard Business School NOM Unit, Working Paper; Harvard Business School: Boston, MA, USA, 2011; pp. 12-16.

86. Noone, B.M.; McGuire, K.A.; Rohlfs, K.V. Social media meets hotel revenue management: Opportunities, issues and unanswered questions. J. Revenues Pricing Manag. 2011, 10, 293-305. [CrossRef]

87. Sweeney, J.C.; Soutar, G.N. Consumer perceived value: The development of a multiple item scale. J. Retail. 2001, 77, 203-220. [CrossRef]

88. Oh, H. Service quality, customer satisfaction, and customer value: A holistic perspective. Int. J. Hosp. Manag. 1999, 18, 67-82. [CrossRef]

89. Kim, K.; Oh, H. Customer satisfaction, service quality, and customer value: Years 2000-2015. Int. J. Contemp. Hosp. Manag. 2017, 29, 2-29.

90. López Fernández, M.C.; Serrano Bedia, A.M. Is the hotel classification system a good indicator of hotel quality? An application in Spain. Tour. Manag. 2004, 25, 771-775. [CrossRef]

(C) 2020 by the authors. Licensee MDPI, Basel, Switzerland. This article is an open access article distributed under the terms and conditions of the Creative Commons Attribution (CC BY) license (http://creativecommons.org/licenses/by/4.0/). 